\title{
BMJ Open Systematic review of incidence and complications of herpes zoster: towards a global perspective
}

\author{
Kosuke Kawai, ${ }^{1}$ Berhanu G Gebremeskel, ${ }^{2}$ Camilo J Acosta ${ }^{1}$
}

To cite: Kawai K,

Gebremeskel BG, Acosta CJ. Systematic review of incidence and complications of herpes zoster: towards a global perspective. BMJ Open 2014:4:e004833.

doi:10.1136/bmjopen-2014004833

- Prepublication history and additional material is available. To view please visit the journal online (http://dx.doi.org/10.1136/ bmjopen-2014-004833)

Received 10 January 2014 Revised 28 April 2014 Accepted 29 April 2014

\section{CrossMark}

\footnotetext{
${ }^{1}$ Global Health Outcomes, Merck \& Co., Inc., West Point, Pennsylvania, USA ${ }^{2}$ School of Public Health, Rutgers, The State University of New Jersey, Piscataway, New Jersey, USA
}

Correspondence to Dr Kosuke Kawai; kkawai@post.harvard.edu

\section{ABSTRACT}

Objective: The objective of this study was to characterise the incidence rates of herpes zoster $(\mathrm{HZ})$, also known as shingles, and risk of complications across the world.

Design: We systematically reviewed studies examining the incidence rates of $\mathrm{HZ}$, temporal trends of $\mathrm{HZ}$, the risk of complications including postherpetic neuralgia (PHN) and HZ-associated hospitalisation and mortality rates in the general population. The literature search was conducted using PubMed, EMBASE and the WHO library up to December 2013.

Results: We included 130 studies conducted in 26 countries. The incidence rate of $\mathrm{HZ}$ ranged between 3 and 5/1000 person-years in North America, Europe and Asia-Pacific, based on studies using prospective surveillance, electronic medical record data or administrative data with medical record review. A temporal increase in the incidence of $\mathrm{HZ}$ was reported in the past several decades across seven countries, often occurring before the introduction of varicella vaccination programmes. The risk of developing PHN varied from $5 \%$ to more than $30 \%$, depending on the type of study design, age distribution of study populations and definition. More than $30 \%$ of patients with PHN experienced persistent pain for more than 1 year. The risk of recurrence of $\mathrm{HZ}$ ranged from $1 \%$ to $6 \%$, with long-term follow-up studies showing higher risk (5-6\%). Hospitalisation rates ranged from 2 to 25/100 000 person-years, with higher rates among elderly populations.

Conclusions: $\mathrm{HZ}$ is a significant global health burden that is expected to increase as the population ages. Future research with rigorous methods is important.

\section{INTRODUCTION}

Herpes zoster (HZ), also known as shingles, is typically characterised by painful, blistering dermatomal rash. ${ }^{2}$ The estimated lifetime risk of $\mathrm{HZ}$ in the general population is approximately 30\%, with the risk increasing sharply after 50 years of age. ${ }^{3}$ After conducting a careful long-term observational study in the 1960s, Hope-Simpson ${ }^{4}$ showed that $\mathrm{HZ}$ results from reactivation of the

\section{Strengths and limitations of this study}

- We comprehensively reviewed the global burden of herpes zoster.

- We found a similar age-specific incidence of herpes zoster in North America, Europe and Asia-Pacific; however, there is a scarcity of research from other regions.

- Because the quality of the study, study design and study population varied widely across studies, we could not synthesise the data quantitatively.

varicella-zoster virus (VZV) in sensory ganglia after a long latency period following primary infection from varicella (chickenpox). In some patients particularly in the elderly, the pain continues to persist after the rash heals and develops into postherpetic neuralgia (PHN), which is the most common complication. PHN causes physical disability, emotional distress and interference with daily activities and sleep. ${ }^{5} \mathrm{HZ}$ also causes neurological sequelae, HZ ophthalmicus (HZO) with eye involvement or disseminated disease. Severe cases of these complications often require hospitalisation.

A live-attenuated VZV vaccine (ZOSTAVAX by Merck) has been demonstrated to significantly reduce the incidences of $\mathrm{HZ}$ and $\mathrm{PHN}$ in addition to the severity and duration of pain associated with HZ. ${ }^{6}$ Public health interventions that promote healthy ageing are increasingly becoming more important, as the elderly population is growing rapidly worldwide. Over the next half century, the proportion of people $\geq 60$ years of age is projected to double, reaching more than $20 \%$ of the total population in all regions of the world. ${ }^{7}$ Moreover, the prevalence of disability in the elderly populations is increasing across the world. ${ }^{8}$

It is essential for healthcare practitioners and health policymakers to be informed by the best available and up-to-date evidence on the HZ burden of disease. In a previous 
review by Thomas and $\mathrm{Hall}^{9}$, there were limited population-based studies on HZ incidence. Since then, many studies have been conducted across countries to examine the incidence rates and temporal trends of HZ. Other reviews have been restricted to specific geographic regions. ${ }^{10}{ }^{11}$ Moreover, to the best of our knowledge, there has been no systematic review of studies examining the risk of complications and hospitalisation. The objective of this study is to characterise the incidence rates of $\mathrm{HZ}$ and risk of complications across the world. We systematically reviewed studies examining the incidence rates of $\mathrm{HZ}$, temporal trends of $\mathrm{HZ}$, risk of HZ complications including PHN and HZ-associated hospitalisation and mortality rates in the general population.

\section{METHODS}

\section{Literature search}

We performed a literature search in PubMed, EMBASE, and the WHO's Global Health Library Regional Index up to December 2013. For PubMed, we used Medical Subject Headings (MeSH) and the title terms 'herpes zoster', 'zoster' or 'shingles' in combination with the term 'incidence'. We also searched eligible articles using $\mathrm{MeSH}$ and the title terms 'postherpetic neuralgia' or 'post-herpetic neuralgia'. We used the same search strategy with text terms in EMBASE and the WHO library. We manually searched the references cited by the retrieved articles and review articles for additional references. Two investigators (KK and BG) independently conducted a systematic review of the literature, assessed study eligibility and extracted data. Discrepancies were settled through discussion with a third investigator (CJA).

\section{Inclusion and exclusion criteria}

We included studies examining the incidence of HZ, risk of PHN, risk of a recurrent episode of HZ, risk of HZO, HZ-associated hospitalisation or HZ-associated mortality. For studies examining the efficacy or effectiveness of vaccination against $\mathrm{HZ}$, we included estimates of incidence rates among unvaccinated individuals. We did not apply language restrictions. We did not include studies limited to children, immunocompromised populations (eg, HIV, cancer and chronic kidney disease) or patients on immunosuppressive therapy (eg, corticosteroids). We also excluded review articles and case reports.

\section{Data extraction}

We developed a standard abstraction form for data extraction. We extracted information regarding authors, publication year, journal, country, study design, study year(s), population, number of cases, number at risk, case definition, case ascertainment, incidence rates of HZ (per 1000 person-years), risk of PHN and other complications, HZ-associated hospitalisation rates and
HZ-associated mortality rates. For studies on incidence that did not report 95\% CI, we computed exact 95\% CI.

\section{RESULTS}

After conducting a literature search, we included 130 studies conducted in 26 countries in this review (figure 1). There were 63 studies on the incidence of HZ from 22 countries $^{3} 4{ }^{6}{ }^{12-71} ; 25$ studies on trends of HZ from 7 countries $^{3} 12 \quad 15-19 \quad 23-25 \quad 27 \quad 28 \quad 4953 \quad 65 \quad 68$ 72-80; 60 studies

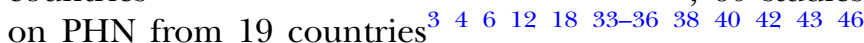
5456 60-63 69 81-118; 9 studies on HZ recurrence from 5 countries $^{4} 12135760$ 119-122; 12 studies on HZO from 5 countries $^{12} 354361$ 123-130; 28 studies on hospitalisation

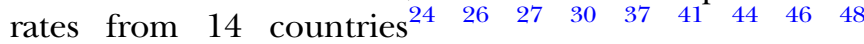
$5255565862-6472737677 \quad 131-137$ and 10 studies on mortality rates from 10 countries. $^{26} 30374144485862134138$

\section{Incidence rates of $\mathrm{HZ}$}

Studies examining the incidence rates of $\mathrm{HZ}$ were conducted in countries from North America $(\mathrm{N}=18)$, Europe $(\mathrm{N}=33)$, Asia $(\mathrm{N}=7)$, South America $(\mathrm{N}=3)$ and the Middle East $(\mathrm{N}=2$; table 1$)$. The incidence rate of HZ ranged between 3 and 5/1000 person-years in North America, Europe and Asia-Pacific, based on studies using prospective surveillance, electronic medical record data or administrative data with medical record review. The age-specific incidence rates of $\mathrm{HZ}$ were similar across countries, with a steep rise after 50 years of age (figure 2). The incidence rate was about $6-8 / 1000$ person-years at 60 years of age and 8-12/1000 personyears at 80 years of age. We observed an increase in the reported incidence rate over time within a country. For example, studies conducted more than 20 years ago in the USA by Ragozzino et $a l^{12}$ and Donahue et $a l^{13}$ showed lower rates compared with studies conducted in recent years. It is noteworthy that prospective population-based studies that identified relatively small numbers of patients with HZ (eg, by Scott et al, ${ }^{33}$ Paul and Thiel, ${ }^{39}$ Di Legami et $a \bar{l}^{5}$ and Lionis $e t a \bar{l}^{9}$ ) estimated lower incidence compared with other studies.

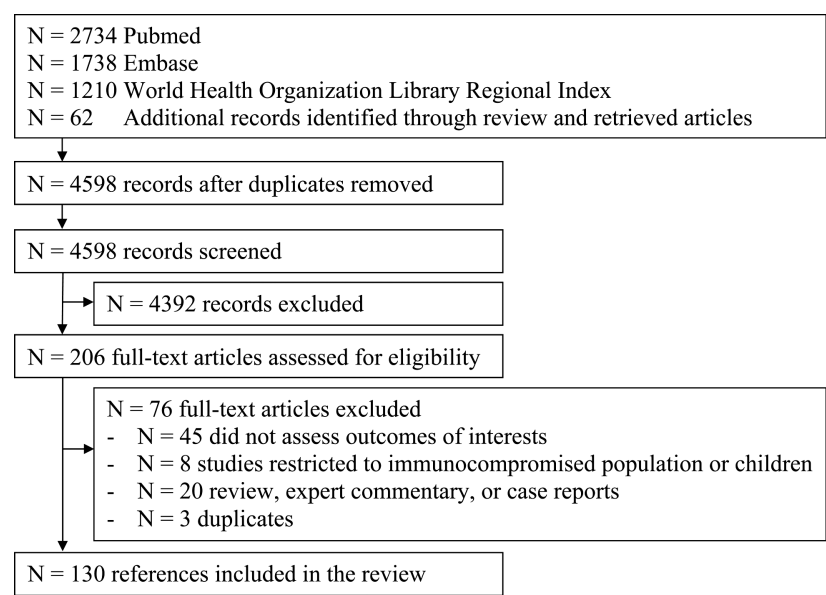

Figure 1 Study selection. 


\begin{tabular}{|c|c|c|c|c|c|c|c|c|}
\hline Country & Author & Study design and population & Case ascertainment & Year & $\begin{array}{l}\mathrm{HZ} \\
\text { cases }\end{array}$ & Age & $\begin{array}{l}\text { Incidence } \\
1000 \text { person- } \\
\text { years }\end{array}$ & $95 \% \mathrm{Cl}$ \\
\hline USA & Ragozzino & Medical records database in Minnesota & $\begin{array}{l}\text { ICD-9 confirmed by medical } \\
\text { records }\end{array}$ & $1945-1959$ & 590 & All ages & 1.31 & 1.15 to $1.35^{\star}$ \\
\hline USA & Donahue & $\begin{array}{l}\text { Health maintenance organisation claims } \\
\text { database in Massachusetts }\end{array}$ & $\begin{array}{l}\text { ICD- } 9 \text { confirmed by medical } \\
\text { records }\end{array}$ & 1990-1992 & 1075 & All ages & 2.15 & 2.02 to $2.28^{*}$ \\
\hline USA & Insinga & MarketScan claims database in the USA & ICD-9 & 2000-2001 & 9152 & All ages & 3.20 & 3.10 to 3.20 \\
\hline USA & Mullooly & $\begin{array}{l}\text { Kaiser Northwest health maintenance } \\
\text { organisation claims database }\end{array}$ & $\begin{array}{l}\text { ICD- } 9 \text { multiplied by positive } \\
\text { predictive value }\end{array}$ & 1997-2002 & 9895 & All ages & 3.69 & 3.58 to 3.82 \\
\hline USA & Yih & $\begin{array}{l}\text { Annual random-digit telephone survey in } \\
\text { Massachusetts }\end{array}$ & Survey from patients & 1999-2003 & 194 & All ages & 4.33 & 3.72 to $4.93^{\star}$ \\
\hline USA & Jumaan & $\begin{array}{l}\text { Health maintenance organisation claims } \\
\text { database in Washington }\end{array}$ & ICD-9 & 1992-2002 & 357 & All ages & 3.71 & \\
\hline USA & Oxman & Zostavax trial in the control group & $\begin{array}{l}\text { Notified by physicians and PCR/ } \\
\text { culture confirmation }\end{array}$ & 1998-2001 & 642 & $\geq 60$ years & 11.12 & \\
\hline USA & Yawn & $\begin{array}{l}\text { Retrospective population-based study } \\
\text { confirmed by medical records in Minnesota }\end{array}$ & $\begin{array}{l}\text { ICD- } 9 \text { confirmed by medical } \\
\text { records }\end{array}$ & $1996-2001$ & 1669 & $\geq 22$ years & 3.60 & 3.40 to 3.70 \\
\hline USA & Rimland & National Veterans Affairs claims database & ICD-9 & 2000-2007† & 28710 & All ages & 5.22 & \\
\hline USA & Leung & MarketScan claims database & ICD-9 & 1993-2006† & 48000 & All ages & 4.40 & 4.30 to 4.40 \\
\hline USA & Tseng & $\begin{array}{l}\text { Kaiser Southern California health } \\
\text { maintenance organisation claims } \\
\text { database in the unvaccinated group }\end{array}$ & ICD-9 & 2007-2009 & 4606 & $\geq 60$ years & 13.0 & 12.6 to 13.3 \\
\hline USA & Langan & $\begin{array}{l}\text { Medicare claims database in the } \\
\text { unvaccinated group }\end{array}$ & ICD-9 & 2007-2009 & 19385 & $\geq 65$ years & 15.1 & 14.9 to 15.3 \\
\hline USA & Chen & $\begin{array}{l}\text { Commercial, Medicare and Medicaid } \\
\text { MarketScan claims database }\end{array}$ & ICD-9 & 2005-2009 & 435378 & $\geq 18$ years & 4.82 & 4.81 to 4.84 \\
\hline USA & Hales & Medicare claims database & ICD-9 & 1992-2010† & 281317 & $\geq 65$ years & 14.2 & 14.0 to 14.5 \\
\hline Canada & Brisson & $\begin{array}{l}\text { Administrative claims database in } \\
\text { Manitoba }\end{array}$ & ICD-9 & $1979-1997 \dagger$ & NA & All ages & 3.48 & \\
\hline Canada & Russell & $\begin{array}{l}\text { Health insurance claims database in } \\
\text { Alberta }\end{array}$ & ICD-9/ICD-10 & 1986-2002† & NA & All ages & 4.30 & \\
\hline Canada & Edgar & $\begin{array}{l}\text { Administrative claims database in British } \\
\text { Columbia }\end{array}$ & ICD-9 & 1994-2003 & 114596 & All ages & 2.89 & \\
\hline Canada & Tanuseputro & Administrative claims database in Ontario & ICD-9 & 1992-2010 & 686763 & All ages & 3.23 & \\
\hline Canada & Russell & $\begin{array}{l}\text { Health insurance claims database in } \\
\text { Alberta }\end{array}$ & ICD-9/ICD-10 & 1994-2010† & 213265 & All ages & 4.50 & \\
\hline UK & Hope-Simpson & $\begin{array}{l}\text { Prospective population-based study in } \\
\text { Cirencester }\end{array}$ & Medical records by GP & 1947-1962 & 192 & All ages & 3.39 & \\
\hline UK & Ross & $\begin{array}{l}\text { Prospective population-based study in } \\
\text { Glasgow }\end{array}$ & Notified by 10 GPs & $1972-1973$ & 87 & All ages & 2.40 & \\
\hline UK & Brisson & RCGP database in England and Wales & ICD-9 medical records by GPs & $1979-1997 \dagger$ & NA & All ages & 3.82 & \\
\hline UK & Brisson & RCGP database in England and Wales & ICD-9 medical records by 69 GPs & $1991-2000$ & NA & All ages & 3.73 & \\
\hline UK & Fleming & RCGP database in England and Wales & ICD-9 medical records by GPs & 1994-2001† & 14532 & All ages & 3.90 & \\
\hline UK & Chapman & RCGP database in England and Wales & ICD-9 medical records by GPs & 1994-2001 & NA & $\geq 15$ years & 3.95 & \\
\hline
\end{tabular}




\begin{tabular}{|c|c|c|c|c|c|c|c|c|}
\hline Country & Author & Study design and population & Case ascertainment & Year & $\begin{array}{l}\mathrm{HZ} \\
\text { cases }\end{array}$ & Age & $\begin{array}{l}\text { Incidence } \\
1000 \text { person- } \\
\text { years }\end{array}$ & $95 \% \mathrm{Cl}$ \\
\hline UK & Scott & $\begin{array}{l}\text { Prospective population-based study } \\
\text { in East London }\end{array}$ & $\begin{array}{l}\text { Notified by } 18 \mathrm{GPs} \text { and PCR } \\
\text { confirmation }\end{array}$ & NA & 186 & All ages & 1.85 & \\
\hline UK & Gauthier & GPRD in UK & Medical records by 603 GPs & 2000-2006 & 27225 & $\geq 50$ years & 5.23 & 5.17 to 5.29 \\
\hline France & Chidiac & Prospective sentinel surveillance & $\begin{array}{l}\text { Notified by } 4635 \text { GPs } \\
\text { and } 513 \text { dermatologists }\end{array}$ & $1997-1998$ & 8103 & All ages & 4.80 & \\
\hline France & Czernichow & Retrospective population-based study & Survey from $744 \mathrm{GPs}$ & 1998 & 605 & All ages & 3.20 & 3.00 to 3.40 \\
\hline France & $\begin{array}{l}\text { Gonzalez- } \\
\text { Chiappe }\end{array}$ & Prospective sentinel surveillance & Notified by 1200 GPs & 2005-2008 & 2375 & All ages & 3.82 & 3.64 to 4.05 \\
\hline France & Mick & Retrospective population-based study & $\begin{array}{l}\text { Survey from } 231 \text { GPs, } 41 \\
\text { dermatologists and } 15 \text { neurologists }\end{array}$ & 2005 & 777 & $\geq 50$ years & 8.99 & 8.34 to 9.64 \\
\hline Germany & Paul & $\begin{array}{l}\text { Prospective population-based study in } \\
\text { Ansbach }\end{array}$ & $\begin{array}{l}\text { Notified by GPs, } \\
\text { dermatologists and others }\end{array}$ & $1992-1993$ & 152 & All ages & 2.26 & \\
\hline Germany & Schiffner-Rohe & $\begin{array}{l}\text { National Statutory Health Insurance claims } \\
\text { database }\end{array}$ & ICD-10 & 2004 & 1170 & $\geq 50$ years & 9.80 & 9.20 to 10.40 \\
\hline Germany & Ultsch & $\begin{array}{l}\text { National Statutory Health Insurance claims } \\
\text { database }\end{array}$ & ICD-10 & $2007-2008$ & 374645 & $\geq 50$ years & 9.60 & 9.56 to 9.63 \\
\hline Germany & Ultsch & $\begin{array}{l}\text { National Statutory Health Insurance claims } \\
\text { database }\end{array}$ & ICD-10 & 2004-2009 & 5384 & All ages & 5.79 & 5.64 to 5.93 \\
\hline $\begin{array}{l}\text { The } \\
\text { Netherlands }\end{array}$ & Opstelten & $\begin{array}{l}\text { Huisartsen Netwerk Utrecht database in } \\
\text { six locations }\end{array}$ & Medical records from 22 GPs & 1994-1999 & 837 & All ages & 3.40 & 2.90 to 3.90 \\
\hline $\begin{array}{l}\text { The } \\
\text { Netherlands }\end{array}$ & de Melker & Prospective sentinel surveillance & Notified by 43 GPs & 1998-2001 & NA & All ages & 3.25 & \\
\hline $\begin{array}{l}\text { The } \\
\text { Netherlands }\end{array}$ & Opstelten & National survey of physicians & Medical records from 104 GPs & 2001 & 1080 & All ages & 3.22 & 3.00 to 3.40 \\
\hline $\begin{array}{l}\text { The } \\
\text { Netherlands }\end{array}$ & Pierik & $\begin{array}{l}\text { Retrospective population-based study in } \\
\text { Almere }\end{array}$ & Medical records from 22 GPs & $2004-2008$ & 3371 & All ages & 4.75 & 4.06 to 5.44 \\
\hline Switzerland & Richard & Prospective sentinel surveillance & Notified by 250 physicians & $1998-2001$ & 2236 & All ages & 2.36 & \\
\hline Belgium & Bilcke & Retrospective population-based study & Notified by 150 GPs & $2000-2007$ & NA & All ages & 3.78 & \\
\hline Spain & Pérez-Farinós & Prospective sentinel surveillance in Madrid & Notified by GPs & 1997-2004† & 1798 & All ages & 3.59 & 3.22 to 3.97 \\
\hline Spain & García Cenoz & Primary care database in Navarre & Medical records from GPs & $2005-2006$ & 4959 & All ages & 4.15 & \\
\hline Spain & Cebrián-Cuenca & $\begin{array}{l}\text { Prospective population-based study in } \\
\text { Valencia }\end{array}$ & Notified by 25 GPs & $2006-2007$ & 146 & $\geq 14$ years & 4.10 & 3.40 to 4.70 \\
\hline Spain & Morant-Talamante & $\begin{array}{l}\text { Electronic medical record database in } \\
\text { Valencia }\end{array}$ & ICD-9 & $2007-2010$ & 85586 & All ages & 4.60 & 4.57 to 4.63 \\
\hline Spain & Esteban-Vasallo & $\begin{array}{l}\text { Electronic medical record in the Madrid } \\
\text { regional public health system }\end{array}$ & ICPC & 2005-2012† & 211650 & All ages & 4.82 & \\
\hline Italy & di Luzio Paparatti & Retrospective population-based study & Survey from 71 GPs & 1995 & 408 & $\geq 15$ years & 4.14 & 3.75 to 4.56 \\
\hline Italy & Di Legami & $\begin{array}{l}\text { Prospective population-based study in } \\
\text { Piedmont }\end{array}$ & Notified by 24 GPs & 2004 & 46 & $\geq 14$ years & 1.74 & 1.28 to 2.32 \\
\hline
\end{tabular}


Table 1 Continued

\begin{tabular}{|c|c|c|c|c|c|c|c|c|}
\hline Country & Author & Study design and population & Case ascertainment & Year & $\begin{array}{l}\mathrm{HZ} \\
\text { cases }\end{array}$ & Age & $\begin{array}{l}\text { Incidence } \\
1000 \text { person- } \\
\text { years }\end{array}$ & $95 \% \mathrm{Cl}$ \\
\hline Italy & Gialloreti & $\begin{array}{l}\text { National primary-care database (Societa } \\
\text { Italiana Medici Generici) }\end{array}$ & Medical records from 342 GPs & 2003-2005 & 5675 & All ages & 4.31 & 4.11 to 4.52 \\
\hline Iceland & Helgason & Prospective population-based study & Notified by 62 GPs & 1990-1995 & 462 & All ages & 2.00 & 1.80 to 2.20 \\
\hline Sweden & Studahl & Swedish National Pharmacy register & $\begin{array}{l}\text { Prescriptions for antiviral } \\
\text { medications }\end{array}$ & 2006-2010 & 127832 & All ages & 2.70 & \\
\hline Greece & Lionis & $\begin{array}{l}\text { Prospective population-based study in rural } \\
\text { Crete }\end{array}$ & Notified by 19 GPs & 2007-2009 & 58 & All ages & 1.60 & \\
\hline Israel & Weitzman & $\begin{array}{l}\text { Maccabi Healthcare Services claims } \\
\text { database }\end{array}$ & ICD-9 & 2006-2010 & 28977 & All ages & 3.46 & \\
\hline Saudi Arabia & Alakloby & $\begin{array}{l}\text { Medical records from the dermatology } \\
\text { clinic }\end{array}$ & $\begin{array}{l}\text { Medical charts from the } \\
\text { dermatologist }\end{array}$ & 1988-2006 & 141 & All ages & 6.20 & 5.18 to $7.22^{*}$ \\
\hline Australia & Stein & $\begin{array}{l}\text { National GP database (Bettering the } \\
\text { Evaluation of Care and Health) }\end{array}$ & Medical records of GPs & 2000-2006 & 379 & $\geq 50$ years & 9.67 & 8.66 to 10.68 \\
\hline Taiwan & Jih & $\begin{array}{l}\text { Taiwan National Health Insurance claims } \\
\text { database }\end{array}$ & ICD-9 & 2000-2006 & 34280 & All ages & 4.89 & 4.76 to $5.04^{*}$ \\
\hline Taiwan & Lin & $\begin{array}{l}\text { Taiwan National Health Insurance claims } \\
\text { database }\end{array}$ & ICD-9 & 2000-2005 & 672782 & All ages & 4.97 & 4.96 to 4.98 \\
\hline Taiwan & Chao & $\begin{array}{l}\text { Taiwan National Health Insurance claims } \\
\text { database }\end{array}$ & ICD-9 & 2000-2008 & 11908 & All ages & 5.67 & \\
\hline South Korea & Park & NA & NA & 1999-2003 & 1089 & All ages & 2.98 & \\
\hline South Korea & Choi & $\begin{array}{l}\text { Health Insurance claims database } \\
\text { (estimated prevalence) }\end{array}$ & ICD-10 & 2003-2007 & 2431744 & All ages & 9.97 & \\
\hline Japan & Toyama & $\begin{array}{l}\text { Prospective population-based study in } \\
\text { Miyazaki }\end{array}$ & Notified by 46 dermatology clinics & 1997-2006 & 48388 & All ages & 4.15 & 4.12 to $4.19^{\star}$ \\
\hline Argentina & Vujacich & $\begin{array}{l}\text { Medical records from the ID reference } \\
\text { centre }\end{array}$ & Medical charts from IDs & 2000-2005 & 302 & All ages & 3.57 & 3.17 to $3.97^{\star}$ \\
\hline Brazil & Castro & $\begin{array}{l}\text { Medical records from the dermatology } \\
\text { clinic }\end{array}$ & $\begin{array}{l}\text { Medical charts from the } \\
\text { dermatologist }\end{array}$ & 1987-1989 & 469 & All ages & $5.62^{\star}$ & \\
\hline Colombia & Gaitan & $\begin{array}{l}\text { Medical records from the oncology, } \\
\text { radiology and nuclear medicine centre }\end{array}$ & $\begin{array}{l}\text { Medical charts from patients } \\
\text { without cancer }\end{array}$ & NA & 75 & NA & $6.50^{*}$ & \\
\hline
\end{tabular}

*We computed the overall estimate or $95 \% \mathrm{Cl}$ based on the study results.

†The estimate from the latest study year.

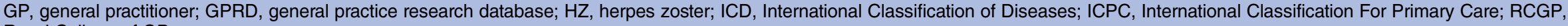

Royal College of GPs. 


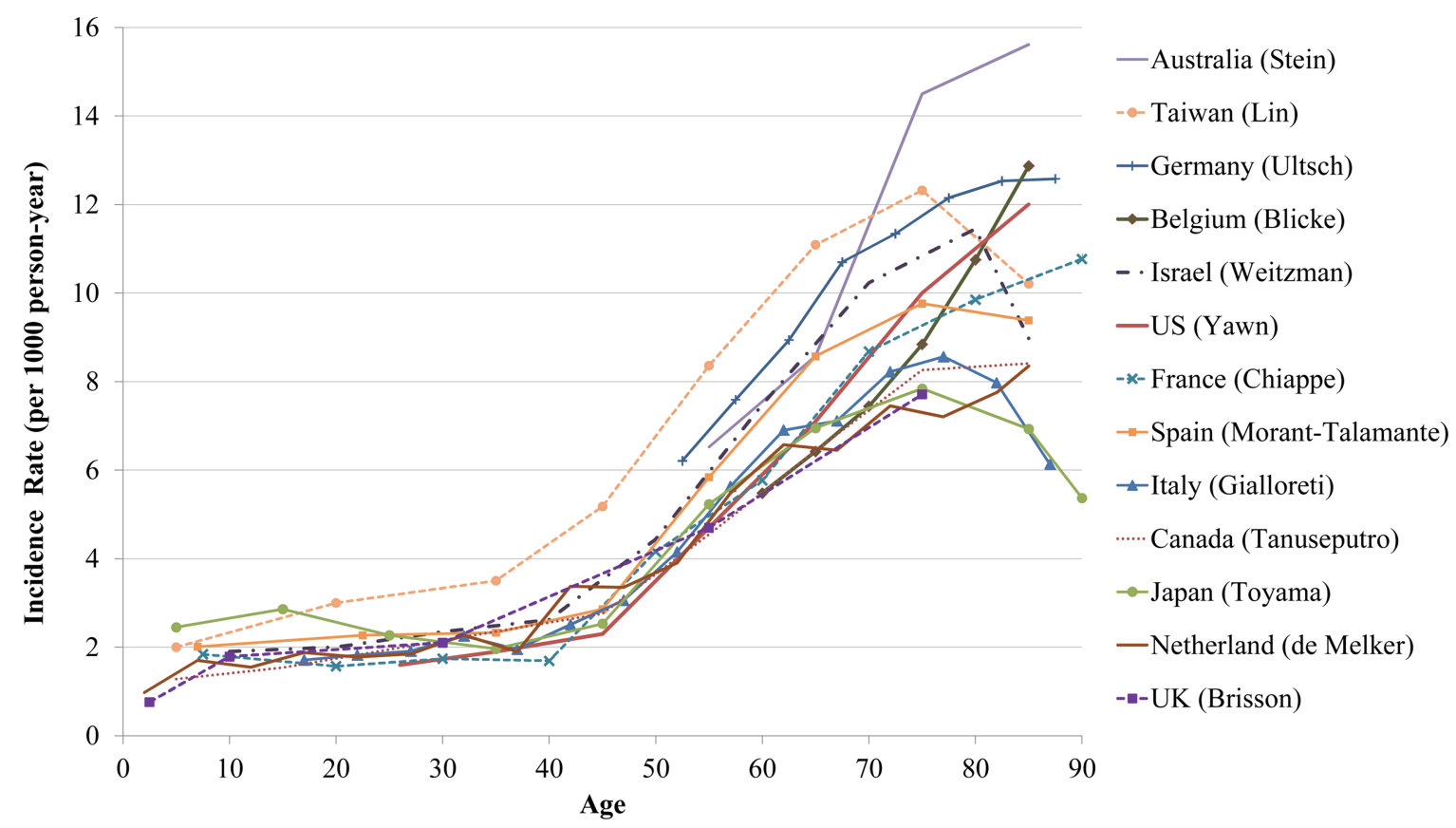

Figure 2 Age-specific incidence rate of herpes zoster in North America, Europe and Asia-Pacific.

\section{Trends of $\mathrm{HZ}$ incidence}

In the USA, studies conducted during the postvaricella vaccination era showed inconsistent results, with some showing no change in incidence but others reporting an increase in $\mathrm{HZ}$ incidence, suggesting a potential impact of varicella vaccination (table 2). However, Leung et al, ${ }^{19}$ Hales $e t a l^{23}$ and Yawn $e t a l^{75}$ examined trends over a longer period and found that incidence rates increased continuously across all age groups before the introduction of the varicella vaccination programme and continued to increase throughout the postvaccination era. These studies concluded that the increase was not due to the varicella vaccination programme. Most studies conducted in Canada, the UK, Spain, Taiwan and Japan reported an increase in the incidence of $\mathrm{HZ}$ over the past decade often occurring in the absence of the national varicella vaccination programmes. ${ }^{24} 25496568$ Several studies in Australia suggested increasing trends in $\mathrm{HZ}$ outpatient visits or hospitalisation during prevaricella and postvaricella vaccination eras. ${ }^{76} 7779$

\section{Risk of PHN}

The risk of developing PHN varied from 5\% to more than $30 \%$ (table 3; 49 studies). The estimated risk of PHN varied by study design, age distribution of study populations and definitions used for PHN. For studies that used multiple definitions of PHN, we present results based on the definition of at least 90 days of persistent pain. Studies that reported risk of PHN by age groups consistently found that older patients have a greater risk of developing PHN (see online supplementary table $\mathrm{S1}$ ). In this review, we found that researchers have used a different duration of persistent pain (persisting for 30 , 90 or 180 days) and severity of pain (clinically meaningful pain or any pain) to define PHN. For example, $18 \%$ of patients had pain for at least 30 days and $10 \%$ for at least 90 days in a population-based study using medical records by Yawn $e t a l^{3}$ in the USA. Similarly, $20 \%$ of patients had pain for at least 30 days and $14 \%$ for at least 90 days in a study by Gauthier $e t a \vec{l}^{34}$ in the UK. Administrative database studies (eg, Ultsch et $a t^{42}(4.5 \%)$, Opstelten et at $t^{43}(2.6 \%)$ and Gialloreti et $\left.a \bar{l}^{56}(6.2 \%)\right)$ were more likely to report a lower estimated risk of PHN compared with other studies. Researchers have used diagnosis and medication data in various algorithms, many of which are not validated. It is noteworthy that retrospective studies involving specialists (eg, Mick et $a p^{88}(32.5 \%)$, Kanbayashi et al ${ }^{102}(52 \%)$ and Ro et $\left.a l^{103}(39.4 \%)\right)$ may have included existing severe cases of patients with PHN and possibly overestimated the overall risk of PHN.

We identified six prospective cohort and three crosssectional studies examining the duration of PHN in North America and Europe (table 4). Several studies reported that PHN may last up to 10 years. Prospective cohort studies demonstrated that approximately $30-50 \%$ of patients with PHN experienced pain lasting for more than 1 year. Cross-sectional studies also reported a similar high proportion of patients with PHN; however, these studies are most likely an overestimate because they are more likely to include patients experiencing a longer duration of pain.

\section{Risk of recurrence}

A limited number $(\mathrm{N}=9)$ of studies examined recurrence of HZ. Four studies reported a risk of $<1.5 \%$, with three of these studies conducted over 1-2 years of follow-up. ${ }^{13} \quad 57 \quad 119 \quad 122$ About 2.9\% of patients had 
Table 2 Temporal trends of herpes zoster

\begin{tabular}{|c|c|c|c|c|}
\hline Country & Author & $\begin{array}{l}\text { Study } \\
\text { periods }\end{array}$ & Varicella vaccination era & Trends \\
\hline USA & Ragozzino & $1945-1959$ & Pre & Incidence increased from 1.1 to $1.5 / 1000$ person-years between $1945-1949$ and $1955-1959$ \\
\hline USA & Jumaan & 1992-2002 & Pre and post (1996-) & Incidence did not change between 1992 and 2002 \\
\hline USA & Yih & $1998-2003$ & Post & Incidence increased from 2.8 to $5.3 / 1000$ person-years between 1999 and 2003 \\
\hline USA & Mullooly & 1997-2002 & Post & Incidence did not change between 1997 and 2002 \\
\hline USA & Yawn & $1996-2005$ & Post & Incidence increased from 3.2 to $4.1 / 1000$ person-years between $1996-1997$ and 2000-2001 \\
\hline USA & Patel & 1993-2004 & Pre and post & Hospitalisation rate did not change during 1993-2000 but increased between 2001 and 2004 \\
\hline USA & Jackson & $1992-2004$ & Pre and post & Hospitalisation rate did not change during 1992-2004 \\
\hline USA & Civen & 2000-2006 & Post & Incidence increased between 2000 and 2006 among unvaccinated adolescents $10-19$ years \\
\hline USA & Rimland & 2000-2007 & Post & Incidence increased from 3.1 to $5.2 / 1000$ person-years between 2000 and 2007 \\
\hline USA & Yawn & 1945-2008 & Pre and post & $\begin{array}{l}\text { Incidence increased from } 0.8 / 1000 \text { person-years in } 1945-1947 \text {, to } 1.6 / 1000 \text { person-years } \\
\text { in } 1980-1982 \text {, to } 3.0 / 1000 \text { person-years in } 2005-2007\end{array}$ \\
\hline USA & Leung & 1993-2006 & Pre and post & Incidence increased from 1.7 to $4.4 / 1000$ person-years between 1993 and 2006 \\
\hline USA & Hales & 1992-2010 & Pre and post & $\begin{array}{l}\text { Incidence increased from } 10.0 \text { to } 13.9 / 1000 \text { person-years between } 1992 \text { and } 2010 \text { in adults } \\
\geq 65 \text { years }\end{array}$ \\
\hline Canada & Brisson & 1979-1997 & Pre & Incidence increased from 2.6 to 3.5/1000 person-years between 1979 and 1997 \\
\hline Canada & Russell & 1986-2002 & Pre and post (2001-) & Incidence increased from 2.8 to $4.2 / 1000$ person-years between 1986 and 2002 \\
\hline Canada & Tanuseputro & 1992-2010 & Pre and post & Incidence did not change during 1992-2009 \\
\hline Canada & Russell & 1994-2010 & Pre and post & Incidence increased from 3.5 to $4.5 / 1000$ person-years between 1994 and 2010 \\
\hline UK & Brisson & 1979-1997 & Pre & Incidence increased from 3.2 to 3.9/1000 person-years between 1979 and 1997 \\
\hline Spain & Perez-Farinos & 1997-2004 & Pre & Incidence increased from 2.5 to $3.6 / 1000$ person-years between 1997 and 2004 \\
\hline Spain & Esteban-Vasallo & 2005-2012 & Pre and post (2006-) & Incidence increased from 3.6 to $4.8 / 1000$ person-years between 2005 and 2012 \\
\hline Australia & Macintyre & 1993-1999 & Pre & Hospitalisation rate increased between 1993 and 1999 \\
\hline Australia & Carville & 1995-2007 & Pre and post (2005-) & Hospitalisation rate increased from 6.3 to 9.1/100 000 person-years between 1995 and 2007 \\
\hline Australia & Nelson & 1998-2009 & Pre and post & Incidence increased from 1.7 to $2.4 / 1000$ person-years between 1998 and 2008 \\
\hline Australia & Jardine & 1998-2007 & Pre and post & Hospitalisation rate did not change during $1992-2009$ \\
\hline Taiwan & Chao & $2000-2008$ & Pre and post & Incidence increased from 4.5 to $6.9 / 1000$ person-years between 2000 and 2008 \\
\hline Taiwan & $\mathrm{Wu}$ & 2000-2009 & Pre and post & Incidence increased from 4.0 to $6.2 / 1000$ person-years between 2000 and 2009 \\
\hline Japan & Toyama & 1997-2006 & Low coverage (20-30\%) & Incidence increased from 3.8 to $4.5 / 1000$ person-years between 1997 and 2006 \\
\hline
\end{tabular}




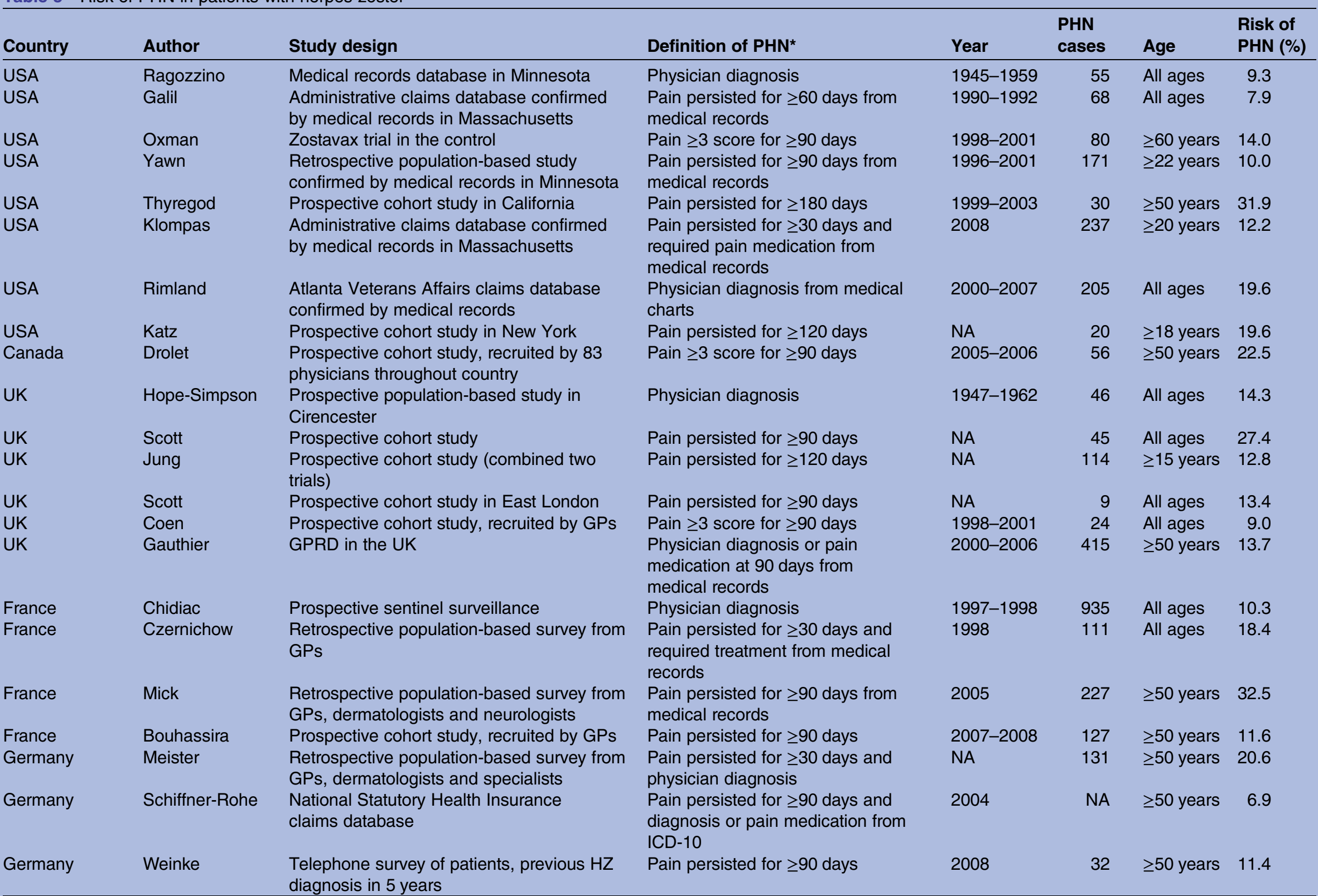




\begin{tabular}{|c|c|c|c|c|c|c|c|}
\hline Country & Author & Study design & Definition of $\mathrm{PHN}^{*}$ & Year & $\begin{array}{l}\text { PHN } \\
\text { cases }\end{array}$ & Age & $\begin{array}{l}\text { Risk of } \\
\text { PHN (\%) }\end{array}$ \\
\hline Germany & Ultsch & $\begin{array}{l}\text { National Statutory Health Insurance claims } \\
\text { database }\end{array}$ & $\begin{array}{l}\text { Pain persisted for } \geq 90 \text { days and } \\
\text { diagnosis or pain medication from } \\
\text { ICD-10 }\end{array}$ & 2004-2009 & 18160 & All ages & 4.5 \\
\hline $\begin{array}{l}\text { The } \\
\text { Netherlands }\end{array}$ & Opstelten & $\begin{array}{l}\text { Huisartsen Netwerk Utrecht database } \\
\text { in six locations }\end{array}$ & $\begin{array}{l}\text { Pain persisted for } \geq 90 \text { days and } \\
\text { required treatment from medical } \\
\text { records }\end{array}$ & 1994-1999 & 22 & All ages & 2.6 \\
\hline $\begin{array}{l}\text { The } \\
\text { Netherlands }\end{array}$ & Opstelten & $\begin{array}{l}\text { Prospective cohort study, recruited by GPs } \\
\text { (PINE trial) }\end{array}$ & Pain $\geq 3$ score for $\geq 90$ days & 2001-2004 & 46 & $\geq 50$ years & 7.1 \\
\hline $\begin{array}{l}\text { The } \\
\text { Netherlands }\end{array}$ & Pierik & Population-based GPs database in Almere & $\begin{array}{l}\text { Physician diagnosis from medical } \\
\text { codes }\end{array}$ & 2004-2008 & 195 & All ages & 5.8 \\
\hline Spain & Cebrian-Cuenca & $\begin{array}{l}\text { Prospective cohort study, recruited by } \\
25 \text { GPs in Valencia }\end{array}$ & Pain persisted for $\geq 90$ days & 2006-2007 & 19 & $\geq 14$ years & 14.5 \\
\hline Spain & Sicras Mainar & $\begin{array}{l}\text { Medical records from six primary care } \\
\text { and one hospital }\end{array}$ & $\begin{array}{l}\text { Physician diagnosis from medical } \\
\text { records }\end{array}$ & $2007-2010$ & 228 & $\geq 30$ years & 15.1 \\
\hline Italy & $\begin{array}{l}\text { di Luzio } \\
\text { Paparatti }\end{array}$ & $\begin{array}{l}\text { Retrospective population-based survey from } \\
\text { GPs }\end{array}$ & $\begin{array}{l}\text { Pain persisted for } \geq 30 \text { days from } \\
\text { medical records }\end{array}$ & 1995 & 275 & $\geq 15$ years & 19.6 \\
\hline Italy & Volpi & $\begin{array}{l}\text { Prospective cohort study, recruited by } \\
\text { dermatologists }\end{array}$ & Pain $\geq 3$ score for $\geq 180$ days & 2001 & 70 & NA & 32.0 \\
\hline Italy & Parruti & $\begin{array}{l}\text { Prospective cohort study, recruited from } \\
\text { GPs and hospitals in Pescara }\end{array}$ & Pain persisted for $\geq 90$ days & 2006-2008 & 130 & NA & 30.0 \\
\hline Italy & Gialloreti & $\begin{array}{l}\text { National primary care database (Societa } \\
\text { Italiana Medici Generici) }\end{array}$ & $\begin{array}{l}\text { Pain persisted for } \geq 90 \text { days and } \\
\text { diagnosis or pain medication from } \\
\text { ICD-9 }\end{array}$ & 2003-2005 & 350 & $\geq 50$ years & 6.2 \\
\hline Italy & Bricout & $\begin{array}{l}\text { Prospective cohort study, recruited } \\
\text { from GPs }\end{array}$ & Pain persisted for $\geq 90$ days & 2009-2010 & 85 & $\geq 50$ years & 20.6 \\
\hline Iceland & Helgason & Prospective population-based study & Physician diagnosis at 90 days & 1990-1995 & 28 & All ages & 7.2 \\
\hline $\begin{array}{l}6 \text { European } \\
\text { countries }\end{array}$ & Lukas & Telephone survey, previous 5 years & Pain persisted for $\geq 90$ days & $\begin{array}{l}2008- \\
2009\end{array}$ & 131 & $\geq 50$ years & 13.0 \\
\hline Israel & Weitzman & $\begin{array}{l}\text { Maccabi Healthcare Services claims } \\
\text { database }\end{array}$ & $\begin{array}{l}\text { ICD-9 code and healthcare service } \\
\text { code }\end{array}$ & 2006-2010 & 1508 & All ages & 5.2 \\
\hline Saudi Arabia & Alakloby & $\begin{array}{l}\text { Medical record database from the } \\
\text { dermatology clinic }\end{array}$ & Physician diagnosis & 1988-2006 & 21 & $\geq 18$ years & 14.9 \\
\hline Australia & Stein & $\begin{array}{l}\text { National GP database (Bettering the } \\
\text { Evaluation of Care and Health) }\end{array}$ & $\begin{array}{l}\text { Physician diagnosis from medical } \\
\text { codes }\end{array}$ & 2000-2006 & 57 & $\geq 50$ years & 15.0 \\
\hline Taiwan & Jih & $\begin{array}{l}\text { Taiwan National Health Insurance claims } \\
\text { database }\end{array}$ & $\begin{array}{l}\text { Pain persisted for } \geq 90 \text { days and } \\
\text { diagnosis or pain medication from } \\
\text { ICD-9 }\end{array}$ & 2000-2006 & 2944 & All ages & 8.6 \\
\hline Taiwan & Tsai & Prospective cohort study in five centres & Pain $\geq 3$ score for $\geq 90$ days & 2008-2009 & 31 & $\geq 50$ years & 20.7 \\
\hline Japan & Kurokawa & $\begin{array}{l}\text { Prospective cohort study in hospitals } \\
\text { and clinics in Hyogo }\end{array}$ & Pain persisted for $\geq 90$ days & NA & 37 & $\geq 20$ years & 26.2 \\
\hline
\end{tabular}


Table 3 Continued

\begin{tabular}{|c|c|c|c|c|c|c|c|}
\hline Country & Author & Study design & Definition of $\mathrm{PHN}^{*}$ & Year & $\begin{array}{l}\text { PHN } \\
\text { cases }\end{array}$ & Age & $\begin{array}{l}\text { Risk of } \\
\text { PHN (\%) }\end{array}$ \\
\hline Japan & Kurokawa & $\begin{array}{l}\text { Prospective cohort study in hospitals } \\
\text { and clinics in Hyogo }\end{array}$ & Pain persisted for $\geq 90$ days & 2001-2003 & 78 & All ages & 24.7 \\
\hline Japan & Kanbayashi & $\begin{array}{l}\text { Retrospective cohort study in pain treatment } \\
\text { hospital }\end{array}$ & Pain persisted for $\geq 90$ days & 2008-2010 & 38 & NA & 52.0 \\
\hline South Korea & Ro & $\begin{array}{l}\text { Retrospective, dermatology department } \\
\text { hospital }\end{array}$ & NA & $2007-2011$ & 826 & NA & 39.4 \\
\hline South Korea & Song & Prospective cohort study in clinics & Pain $\geq 3$ score for $\geq 90$ days & 2009-2010 & 58 & $\geq 50$ years & 38.4 \\
\hline South Korea & Cho & Prospective cohort study in clinics & Pain $\geq 3$ score for $\geq 90$ days & 2010-2012 & 19 & $\geq 18$ years & 6.2 \\
\hline Thailand & Tunsuriyawong & $\begin{array}{l}\text { Retrospective study of medical records } \\
\text { at hospital }\end{array}$ & $\begin{array}{l}\text { Physician diagnosis from medical } \\
\text { record }\end{array}$ & 1995-2000 & 67 & All ages & 16.8 \\
\hline Thailand & Aunhachoke & Prospective cohort study, recruited by GPs & Pain persisted for $\geq 90$ days & 2007-2008 & 35 & $\geq 50$ years & 19.4 \\
\hline Singapore & Goh & $\begin{array}{l}\text { Prospective cohort study in dermatology } \\
\text { clinic }\end{array}$ & Pain persisted for $\geq 90$ days & 1994-1995 & 46 & All ages & 28.0 \\
\hline India & Chaudhary & NA & NA & NA & 33 & NA & 14.3 \\
\hline India & Abdul Latheef & NA & NA & NA & 21 & All ages & 10.2 \\
\hline Argentina & Vujacich & $\begin{array}{l}\text { Medical record database from ID } \\
\text { reference centre }\end{array}$ & $\begin{array}{l}\text { Pain persisted for } \geq 60 \text { days and } \\
\text { diagnosis from medical records }\end{array}$ & 2000-2005 & 39 & All ages & 12.9 \\
\hline Argentina & Vujacich & Prospective cohort study, recruited by GPs & Pain $\geq 3$ score for $\geq 90$ days & NA & 11 & $\geq 50$ years & 11.5 \\
\hline
\end{tabular}

*For studies that used multiple definitions of PHN, we present results based on the definition that used at least 90 days of persistent pain

GP, general practitioner; GPRD, general practice research database; HZ, herpes zoster; ICD, International Classification of Diseases; PHN, postherpetic neuralgia. 


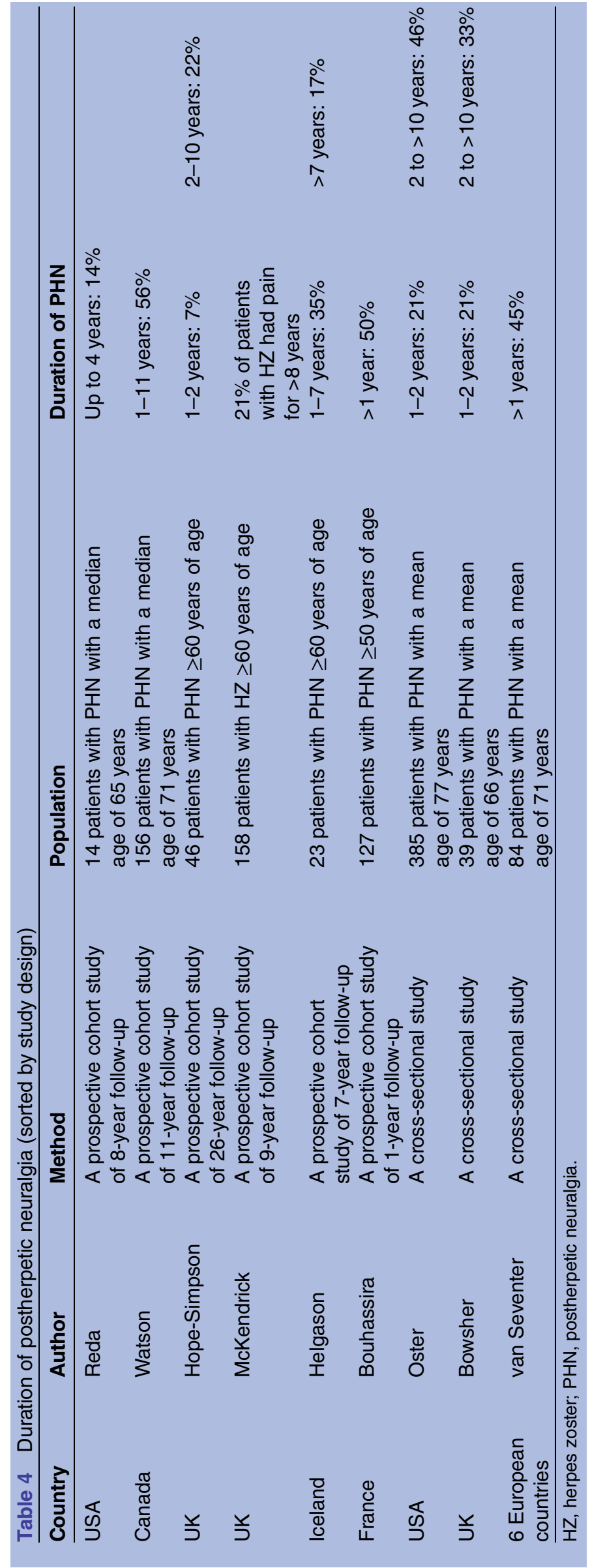

recurrence of $\mathrm{HZ}$ in Israel during 2 years of follow-up, while $2.3 \%$ of patients had recurrence in South Korea up to 10 years of obervation..$^{60121}$ However, studies with a long-term follow-up period tended to report a higher risk of recurrence. Hope-Simpson et $a l^{115}$ reported that $4.7 \%$ had recurrence of $\mathrm{HZ}$ during 16 years of follow-up in the UK. Similarly, Ragozzino et $a l^{12}$ reported that $5.3 \%$ of patients had episodes of recurrence during more than 20 years of follow-up. A recent study by Yawn et $a l^{120}$ also demonstrated that a recurrence of $\mathrm{HZ}$ occurred with a rate of $6.2 \%$ after 8 years of follow-up. The risk of recurrence may also depend on immune status. ${ }^{120}$ Thus, overall risk of recurrence may vary by inclusion of those immunocompromised individuals.

\section{Risk of HZO}

HZO occurs when VZV reactivation affects the distribution of the ophthalmic division of the trigeminal nerve and can occur with or without eye involvement. Although the number of population-based studies is limited, similar risks of $\mathrm{HZO}$ were reported across studies. The reported risks of HZO among patients with $\mathrm{HZ}$ were $10.1 \%$ (Ragozzino et al, ${ }^{12}$ USA), $12.3 \%$ (Chidiac et $a l l^{35}$ France), $14.4 \%$ (Opstelten et $a l,{ }^{43}$ the Netherlands) and $14.9 \%$ (Alakloby et al, ${ }^{61}$ Saudi Arabia). Borkar et $a l^{124}$ reported an overall incidence of 30.9/ 100000 person-years, which corresponds to an approximately $10 \%$ risk among patients with $\mathrm{HZ}$ in the USA. As has been previously recognised, the risk of $\mathrm{HZO}$ is similar across age groups. ${ }^{123} 124$

A wide range of eye complications, such as keratitis, uveitis and conjunctivitis, could result from HZO. The reported risk of these eye complications in patients with $\mathrm{HZO}$ ranged widely from approximately $30 \%$ to $78 \% .{ }^{125-129}$ In a population-based study in the USA, the risk of $\mathrm{HZO}$ with eye involvement among patients with $\mathrm{HZ}$ was $2.5 \% .{ }^{130}$ The HZ-associated eye complications required an average of 10 months of medical care with $6 \%$ of cases resulting in vision loss. ${ }^{130}$

\section{Hospitalisation rates associated with $\mathrm{HZ}$}

We identified 28 studies that reported HZ-associated hospitalisation (table 5). All studies used hospital discharge or claims data. Rates of HZ-related hospitalisation ranged widely from 2 to $25 / 100000$ person-years in studies examining all ages. The variation in the estimates may reflect the differing admission criteria in the different settings. Hospitalisations with a primary diagnosis of HZ accounted for about 29-42\% of HZ-related hospitalisations. ${ }^{3762}{ }^{73}$ Studies that included hospitalisations with non-primary diagnosis codes (eg, secondary) may have overestimated the hospitalisation rate because they may represent prior or incidental HZ. Hospitalisation rates increased steeply with age, with the majority of the cases occurring in adults $\geq 50$ years of age. For example, Jackson et $a l^{73}$ reported HZ-associated hospitalisation rates (confirmed with medical records) ranging from $10 / 100000$ in adults $60-69$ years of age to $65 / 100000$ in 
Table 5 Hospitalisation rates associated with herpes zoster

\begin{tabular}{|c|c|c|c|c|c|c|c|}
\hline Country & Author & Study design/database & Case ascertainment & Years & Age & $\begin{array}{l}\text { Hospitalisation, } \\
100000 \\
\text { person-years }\end{array}$ & Older age group \\
\hline USA & Lin & $\begin{array}{l}\text { Hospital discharge data in } \\
\text { Connecticut }\end{array}$ & ICD-9 primary or secondary & 1986-1995 & All ages & 16.1 & 144.2 in $\geq 80$ years \\
\hline USA & Coplan & Kaiser Northern California & $\begin{array}{l}\text { ICD-9 primary confirmed by } \\
\text { medical charts }\end{array}$ & 1994 & All ages & 2.1 & 9.3 in $\geq 60$ years \\
\hline USA & Patel & National inpatient sample data & ICD-9 any diagnostic position & 1993-2004 & All ages & 25.0 & 112.3 in $\geq 60$ years \\
\hline USA & Jackson & $\begin{array}{l}\text { Group Health in Washington } \\
\text { medical records }\end{array}$ & $\begin{array}{l}\text { ICD- } 9 \text { primary confirmed by } \\
\text { medical charts }\end{array}$ & 1992-2004 & $\geq 50$ years & 14.0 & 65.1 in $\geq 80$ years \\
\hline Canada & Brisson & Hospital claims in Manitoba & ICD-9 any diagnostic position & 1979-1997 & All ages & NA & 86.0 in $\geq 65$ years \\
\hline Canada & Edgar & $\begin{array}{l}\text { Ministry of health service data } \\
\text { in British Columbia }\end{array}$ & $\begin{array}{l}\text { ICD-9/ICD-10 any diagnostic } \\
\text { position }\end{array}$ & 1994-2003 & All ages & 10.0 & 99.0 in $\geq 80$ years \\
\hline Canada & Tanuseputro & Hospital discharge data in Ontario & $\begin{array}{l}\text { ICD-9/ICD-10 any diagnostic } \\
\text { position }\end{array}$ & 1992-2010 & All ages & 6.7 & 75.0 in $\geq 80$ years \\
\hline UK & Brisson & $\begin{array}{l}\text { Hospitalisation episode } \\
\text { statistics in England }\end{array}$ & $\begin{array}{l}\text { ICD-9/ICD-10 any diagnostic } \\
\text { position }\end{array}$ & 1995-1996 & All ages & NA & 148.0 in $\geq 65$ years \\
\hline UK & Brisson & $\begin{array}{l}\text { Hospitalisation episode } \\
\text { statistics in England }\end{array}$ & ICD-10 primary diagnosis & $1991-2000$ & All ages & 4.4 & 19.1 in $\geq 60$ years \\
\hline France & $\begin{array}{l}\text { Gonzalez- } \\
\text { Chiappe }\end{array}$ & National hospital data & ICD-10 primary diagnosis & 2005-2008 & All ages & 4.1 & - \\
\hline Germany & Ultsch & Federal health monitoring system & ICD-10 primary diagnosis & 2007-2008 & $\geq 50$ years & 44.6 & 102.5 in $\geq 80$ years \\
\hline $\begin{array}{l}\text { The } \\
\text { Netherlands }\end{array}$ & de Melker & National healthcare registry & $\begin{array}{l}\text { ICD-9/ICD-10 primary or } \\
\text { secondary }\end{array}$ & 1998-2001 & All ages & 2.7 & 19.0 in $\geq 80$ years \\
\hline $\begin{array}{l}\text { The } \\
\text { Netherlands }\end{array}$ & Pierik & $\begin{array}{l}\text { Retrospective population-based } \\
\text { study, GPs in Almere }\end{array}$ & Hospital referrals by GPs & 2004-2008 & All ages & 15.5 & - \\
\hline Belgium & Bilcke & National Christian Sickness Fund & ICD-9 primary or secondary & 2000-2007 & All ages & 14.2 & 85.0 in $\geq 80$ years \\
\hline Spain & Gil & National hospital data & ICD-9 any diagnostic position & $1999-2000$ & All ages & 8.4 & - \\
\hline Spain & Gil & National hospital data & ICD-9 primary or secondary & 1998-2004 & $\geq 30$ years & 13.4 & 54.3 in $\geq 80$ years \\
\hline Spain & Bayas & National hospital data in Catalonia & ICD-9 any diagnostic position & $1993-2003$ & All ages & 9.7 & - \\
\hline Spain & $\begin{array}{l}\text { Morant- } \\
\text { Talamante }\end{array}$ & $\begin{array}{l}\text { Electronic medical record } \\
\text { database in Valencia }\end{array}$ & ICD-9 any diagnostic position & 2007-2010 & All ages & 3.0 & 15.7 in $\geq 80$ years \\
\hline Spain & Gil-Prieto & National hospital data & ICD-9 any diagnostic position & 2005-2010 & All ages & 10.3 & - \\
\hline Italy & Di Legami & $\begin{array}{l}\text { Hospital discharge } \\
\text { records in Piemonte }\end{array}$ & ICD-9 primary or secondary & 2004 & $\geq 14$ years & 12.0 & 46.0 in $\geq 80$ years \\
\hline Italy & Gialloreti & National hospital discharge records & ICD-9 primary diagnosis & 2003-2005 & All ages & 5.6 & 26.0 in $\geq 80$ years \\
\hline Portugal & Mesquita & National public hospital data & ICD-9 primary diagnosis & 2000-2010 & All ages & 1.9 & - \\
\hline Sweden & Studahl & National patient register & ICD-10 primary diagnosis & 2006-2010 & All ages & 6.9 & - \\
\hline
\end{tabular}




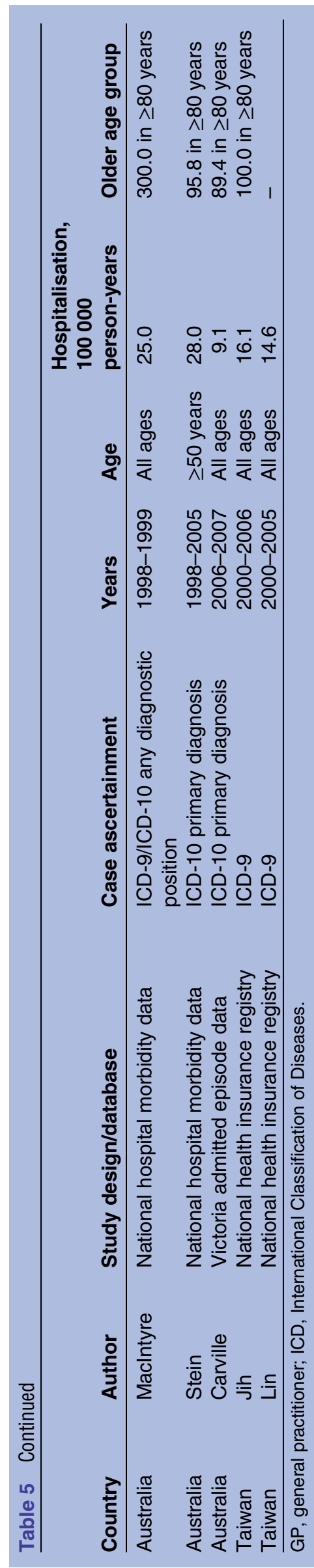

adults $\geq 80$ years of age in the USA. Similarly, the rate of hospitalisation with primary diagnosis of $\mathrm{HZ}$ ranged from 13/100 000 in adults 60-64 years of age to 96/ 100000 in adults $\geq 80$ years of age in Australia. ${ }^{62}$ The rates ranged from 31/100 000 in adults 60-64 years of age to $100 / 100000$ in adults $\geq 80$ years of age in Germany. ${ }^{41}$

\section{Mortality rates associated with $\mathrm{HZ}$}

Mortality rates associated with $\mathrm{HZ}$ ranged from 0.017 to 0.465/100 000 person-years in studies (see online supplementary table S2). Most studies reported that the majority of deaths occurred in adults $\geq 60$ years of age.

\section{DISCUSSION}

$\mathrm{HZ}$ is a significant global health burden that is expected to increase as the population ages. The incidence rises steeply after 50 years of age and many working-age adults and elderly individuals are at increased risk. Risk of complications, particularly debilitating and longlasting PHN, and hospitalisation is common in the elderly population. The major strength of our study is that we assessed the HZ burden across the globe and comprehensively reviewed incidence, risk of complications, hospitalisation and mortality. Our review included 63 studies on incidence, substantially more than the prior review by Thomas and Hall, ${ }^{9}$ which included 17 studies with overall incidence ranging from 1.2 to 4.8/ 1000 person-years. Other reviews were restricted to specific geographic regions and/or assessed only incidence. $^{10} 11$

Relatively similar estimates of the HZ incidence rate (between 3 and 5/1000 person-years) were reported in North America, Europe and Asia-Pacific. However, we observed some variations in estimates most likely due to the various study designs, case ascertainments, age distributions of the population and year of the study. It is difficult to accurately estimate the incidence rates because it is not a commonly reportable disease and surveillance systems are not usually in place. Most studies had limitations in their study methodology. Almost all studies may be susceptible to under-reporting due to patients who did not seek medical care. However, administrative database studies using diagnostic and billing codes may have overestimated the incidence due to misclassification. Several validation studies reported a relatively high sensitivity for the International Classification of Diseases (ICD)-9 code (98\%) and positive predictive value (PPV; 84-94\%). ${ }^{1583}{ }^{139}$ Furthermore, studies using administrative insurance data may lack generalisability because they may not be representative of the general population. Population-based surveillance studies face difficulty in estimating the numbers of the population at risk in the study catchment area. Several prospective cohort studies that identified relatively small numbers of patients with $\mathrm{HZ}$ (eg, by Scott et al, Paul and Thiel, Di Legami et al and Lionis et al) may have 
underestimated the rate of $\mathrm{HZ}$ due to under-reporting of cases or inaccuracy in estimating the numbers of the population at risk. In spite of these limitations, it is reassuring to find similar incidences across countries in well-conducted studies.

There is a scarcity of research examining the incidence of $\mathrm{HZ}$ in Asia, Latin America and Africa. HZ may be regarded as a low health priority in many of these countries; however, the proportion of people $\geq 60$ years of age is projected to double in the next several decades, and the numbers of $\mathrm{HZ}$ cases are expected to increase substantially. Further research is needed because it is unclear whether the incidence would be similar in these regions. Age-specific incidence rates may vary because of the regional differences in epidemiology of varicella infection and VZV genotype distribution. Varicella primarily affects young children in temperate countries, whereas varicella tends to occur at a later age during adolescence and adulthood, presenting in severe form with frequent risks of complication and mortality in tropical countries. ${ }^{140}{ }^{141}$ Severe varicella infections during adolescence may result in greater numbers of VZVs remaining latent and possibly resulting in earlier reactivation of VZV. ${ }^{142}$ The distribution of VZV clades varies globally. ${ }^{143}{ }^{144}$ VZV can be classified into at least five major clades. VZV clades 1 and 3 are dominant strains in Europe and the Americas, whereas clade 2 is a dominant strain in Asia and clade 5 in Africa. ${ }^{143}$ Molecular epidemiology of VZV is still an active area of investigation and requires more research. Furthermore, the incidence of HZ may be higher in the countries heavily affected by HIV/AIDS or other immunocompromising conditions.

Hope-Simpson ${ }^{4}$ hypothesised that exogenous exposure to VZV from individuals with varicella or HZ may boost VZV-specific cell-mediated immunity and thereby decrease the risk of HZ. Because varicella vaccination programmes reduce VZV circulating in the community, thus potentially leading to a decrease in the opportunity for boosting immunity against VZV, it has been hypothesised that the introduction of varicella vaccination might increase the incidence of $\mathrm{HZ}$ in the population. However, based on the current literature, there is no conclusive evidence as to whether varicella vaccination programmes have been associated with an increase in the incidence of HZ. In fact, a number of studies across countries have found an increase in the incidence of $\mathrm{HZ}$ before introduction of the varicella vaccination programme. It is unclear why the incidence of $\mathrm{HZ}$ is increasing. The temporal change or emergence of infectious disease is usually due to changes in the society, technology, virus itself or environment, such as climate change. ${ }^{145}$ The temporal increase was independent of age. It may partly be explained by an increase in the prevalence of risk factors, an increase in the use of immunosuppressive agents (eg, chemotherapy) or an increase in diagnosis through improved access to healthcare and public awareness. Because HZ is usually clinically diagnosed, diagnostic modalities are unlikely to have affected the reported incidences. Given the steady continuous increase in the incidence of $\mathrm{HZ}$ across age groups, it is plausible that a genetic change in the VZV may be playing a role. For example, a study in the UK suggested that changes in genotype distribution have occurred through importation of different strains. ${ }^{146}$ Although VZV is considered a genetically stable virus, a recombination between different VZV strains could possibly occur. ${ }^{143} 147$

We reviewed the risk of PHN in patients with HZ. Several long-term prospective cohort studies demonstrated that more than $30 \%$ of patients with PHN could experience pain lasting for more than 1 year. The reported risk of developing $\mathrm{PHN}$ in patients with $\mathrm{HZ}$ varied widely from $5 \%$ to more than $30 \%$. The risk of PHN may have differed across countries due to the varying prevalence of disability and other underlying comorbidities in the elderly population. ${ }^{8}{ }^{148}$ However, we could not conclude whether the risk of PHN differed by country because of wide variation. The wide variation in the estimates could be partly due to the different study designs used in prior studies. Prospective cohort studies of patients with $\mathrm{HZ}$ tend to report greater risk of PHN than studies utilising electronic medical records or administrative databases. We found that administrative database studies often face a numbers of challenges in identifying patients with PHN and they are likely to underestimate the risk of PHN. Currently, there is only one study, by Klompas $e t a l{ }^{83}$ that developed and validated an algorithm for PHN using ICD-9 codes and claims for a filled prescription. The algorithm detected PHN with a sensitivity of $86 \%$ and PPV of $78 \%$; however, they defined PHN as a persistent pain for 30 days or more after zoster onset rather than 90 days or more. More validation studies are needed.

Researchers used different definitions of PHN. A difficulty in reaching consensus on a definition for PHN is probably due to a multifactorial pathophysiological nature of the condition and difficulty in objectively assessing the pain. ${ }^{149}$ Patients with PHN also experience different types of pain including a steady burning pain, a sudden stabbing pain or stimulus-evoked pain (allodynia). The best option for defining PHN would be clinically meaningful pain lasting for more than 90 days after rash onset, considering the pathophysiology and definitions suggested from prior trials on antiviral treatment and zoster vaccination. ${ }^{6} 150151$ We also believe that healthcare utilisation patterns and prescribed treatment for PHN vary across countries and that characterising the treatment patterns would be important for future research.

Several prior studies with a long-term follow-up found that recurrence of $\mathrm{HZ}$ is frequent, with a rate of $5-6 \%$, which is comparable to rates of first occurrence of HZ. However, a limited number of studies examined the risk of recurrence and more studies are needed to confirm these findings. There were a limited number of population-based studies examining HZO, a severe condition that may lead to significant visual impairment. 
Several limitations of this review are worth noting. Because the quality of the study, study design and age distribution of population varied widely across studies, we could not synthesise the data quantitatively to estimate the pooled incidence rates. We did not conduct a formal study quality assessment. However, we described the study design and outcome ascertainment of each study and discussed limitations of studies. Our review focused on general populations, primarily immunocompetent populations, and we did not include studies restricted to immunocompromised populations (such as HIV/AIDS, malignancy or autoimmune disease). Our review also did not include uncommon complications of HZ, such as Ramsay Hunt syndrome, Bell's palsy and transverse myelitis.

In conclusion, similar age-specific incidence of $\mathrm{HZ}$ was reported in North America, Europe and Asia-Pacific; however, there is a scarcity of research from other regions. Risk of complications, particularly $\mathrm{PHN}$, and hospitalisation is common in the elderly population. HZ is a global health burden that is expected to increase as the population ages across the world in the near future. The prevalence of disability in the elderly populations is also increasing. It is important for healthcare practitioners and health policymakers to consider implementing effective preventive measures such as vaccination against $\mathrm{HZ}$ across the globe.

Contributors $\mathrm{KK}, \mathrm{BG}$ and CJA designed the study. KK and BG conducted the literature search and extracted data. KK wrote the first draft of the manuscript. $\mathrm{KK}, \mathrm{BG}$ and CJA interpreted the data, critically revised the manuscript and approved the final version of this manuscript.

Funding Merck \& Co, Inc.

Competing interests KK is a consultant working for Merck \& Co, Inc. BG is a research fellow funded by Merck \& Co, Inc. CJA is employed by Merck \& Co, Inc.

Provenance and peer review Not commissioned; externally peer reviewed.

Data sharing statement No additional data are available.

Open Access This is an Open Access article distributed in accordance with the Creative Commons Attribution Non Commercial (CC BY-NC 3.0) license, which permits others to distribute, remix, adapt, build upon this work noncommercially, and license their derivative works on different terms, provided the original work is properly cited and the use is non-commercial. See: http:// creativecommons.org/licenses/by-nc/3.0/

\section{REFERENCES}

1. Cohen Jl. Clinical practice: herpes zoster. N Engl J Med 2013;369:255-63.

2. Dworkin $\mathrm{RH}$, Johnson RW, Breuer J, et al. Recommendations for the management of herpes zoster. Clin Infect Dis 2007;44(Suppl 1): S1-26.

3. Yawn BP, Saddier P, Wollan PC, et al. A population-based study of the incidence and complication rates of herpes zoster before zoster vaccine introduction. Mayo Clin Proc 2007;82:1341-9.

4. Hope-Simpson RE. The nature of herpes zoster: a long-term study and a new hypothesis. Proc R Soc Med 1965;58:9-20.

5. Johnson RW, Bouhassira D, Kassianos G, et al. The impact of herpes zoster and post-herpetic neuralgia on quality-of-life. BMC Med 2010;8:37.

6. Oxman MN, Levin MJ, Johnson GR, et al. A vaccine to prevent herpes zoster and postherpetic neuralgia in older adults. $N$ Engl J Med 2005;352:2271-84
7. World Population Prospects: The 2012 Revision. United Nations, Department of Economic and Social Affairs, Population Division, 2013.

8. World report on disability. World Health Organization and the World Bank, 2011.

9. Thomas SL, Hall AJ. What does epidemiology tell us about risk factors for herpes zoster? Lancet Infect Dis 2004;4:26-33.

10. Araújo LQ, Macintyre CR, Vujacich C. Epidemiology and burden of herpes zoster and post-herpetic neuralgia in Australia, Asia and South America. Herpes 2007;14(Suppl 2):40-4.

11. Pinchinat S, Cebrián-Cuenca AM, Bricout $\mathrm{H}$, et al. Similar herpes zoster incidence across Europe: results from a systematic literature review. BMC Infect Dis 2013;13:170.

12. Ragozzino MW, Melton LJ, Kurland LT, et al. Population-based study of herpes zoster and its sequelae. Medicine (Baltimore) 1982;61:310-16

13. Donahue JG, Choo PW, Manson JE, et al. The incidence of herpes zoster. Arch Intern Med 1995;155:1605-9.

14. Insinga RP, Itzler RF, Pellissier JM, et al. The incidence of herpes zoster in a United States administrative database. J Gen Intern Med 2005;20:748-53.

15. Mullooly JP, Riedlinger K, Chun C, et al. Incidence of herpes zoster, 1997-2002. Epidemiol Infect 2005;133:245-53.

16. Yih WK, Brooks DR, Lett SM, et al. The incidence of varicella and herpes zoster in Massachusetts as measured by the Behavioral Risk Factor Surveillance System (BRFSS) during a period of increasing varicella vaccine coverage, 1998-2003. BMC Public Health 2005;5:68.

17. Jumaan AO, Yu O, Jackson LA, et al. Incidence of herpes zoster, before and after varicella-vaccination-associated decreases in the incidence of varicella, 1992-2002. J Infect Dis 2005;191: 2002-7.

18. Rimland D, Moanna A. Increasing incidence of herpes zoster among veterans. Clin Infect Dis 2010;50:1000-5.

19. Leung J, Harpaz R, Molinari NA, et al. Herpes zoster incidence among insured persons in the United States, 1993-2006: evaluation of impact of varicella vaccination. Clin Infect Dis 2011;52:332-40.

20. Tseng HF, Smith N, Harpaz R, et al. Herpes zoster vaccine in older adults and the risk of subsequent herpes zoster disease. JAMA 2011;305:160-6.

21. Langan SM, Smeeth L, Margolis DJ, et al. Herpes zoster vaccine effectiveness against incident herpes zoster and post-herpetic neuralgia in an older US population: a cohort study. PLoS Med 2013;10:e1001420.

22. Chen SY, Suaya JA, Li Q, et al. Incidence of herpes zoster in patients with altered immune function. Infection 2014;42:325-34.

23. Hales CM, Harpaz R, Joesoef MR, et al. Examination of links between herpes zoster incidence and childhood varicella vaccination. Ann Intern Med 2013;159:739-45.

24. Brisson M, Edmunds WJ, Law B, et al. Epidemiology of varicella zoster virus infection in Canada and the United Kingdom. Epidemiol Infect 2001;127:305-14.

25. Russell ML, Schopflocher DP, Svenson L, et al. Secular trends in the epidemiology of shingles in Alberta. Epidemiol Infect 2007;135:908-13.

26. Edgar BL, Galanis E, Kay C, et al. The burden of varicella and zoster in British Columbia 1994-2003: baseline assessment prior to universal vaccination. Can Commun Dis Rep 2007;33 $1-15$

27. Tanuseputro P, Zagorski B, Chan KJ, et al. Population-based incidence of herpes zoster after introduction of a publicly funded varicella vaccination program. Vaccine 2011;29:8580-4

28. Russell ML, Dover DC, Simmonds KA, et al. Shingles in Alberta: before and after publicly funded varicella vaccination. Vaccine 2013. doi:10.1016/j.vaccine.2013.09.018. [Epub ahead of print 4 Oct 2013]

29. Ross CA, Brown WK, Clarke A, et al. Herpes zoster in genera practice. J R Coll Gen Pract 1975;25:29-32.

30. Brisson M, Edmunds WJ. Epidemiology of varicella-zoster virus in England and Wales. J Med Virol 2003;70(Suppl 1):S9-14.

31. Fleming DM, Cross KW, Cobb WA, et al. Gender difference in the incidence of shingles. Epidemiol Infect 2004;132:1-5.

32. Chapman RS, Cross KW, Fleming DM. The incidence of shingles and its implications for vaccination policy. Vaccine $2003 ; 21$ : 2541-7.

33. Scott FT, Leedham-Green ME, Barrett-Muir WY, et al. A study of shingles and the development of postherpetic neuralgia in East London. J Med Virol 2003;70(Suppl 1):S24-30.

34. Gauthier A, Breuer J, Carrington D, et al. Epidemiology and cost of herpes zoster and post-herpetic neuralgia in the United Kingdom. Epidemiol Infect 2009;137:38-47. 
35. Chidiac C, Bruxelle J, Daures JP, et al. Characteristics of patients with herpes zoster on presentation to practitioners in France. Clin Infect Dis 2001;33:62-9.

36. Czernichow S, Dupuy A, Flahault A, et al. [Herpes zoster: incidence study among "sentinel" general practitioners]. Ann Dermatol Venereol 2001;128:497-501.

37. Gonzalez Chiappe S, Sarazin M, Turbelin C, et al. Herpes zoster: burden of disease in France. Vaccine 2010;28:7933-8.

38. Mick G, Gallais JL, Simon F, et al. [Burden of herpes zoster and postherpetic neuralgia: incidence, proportion, and associated costs in the French population aged 50 or over]. Rev Epidemiol Sante Publique 2010;58:393-401.

39. Paul E, Thiel T. [Epidemiology of varicella zoster infection. Results of a prospective study in the Ansbach area]. Hautarzt 1996;47:604-9.

40. Schiffner-Rohe J, Jow S, Lilie HM, et al. [Herpes zoster in Germany. A retrospective analyse of SHL data] MMW Fortschr Med 2010;151(Suppl 4):193-7.

41. Ultsch B, Siedler A, Rieck T, et al. Herpes zoster in Germany: quantifying the burden of disease. BMC Infect Dis 2011;11:173.

42. Ultsch B, Köster I, Reinhold T, et al. Epidemiology and cost of herpes zoster and postherpetic neuralgia in Germany. Eur J Health Econ 2013;14:1015-26.

43. Opstelten W, Mauritz JW, de Wit NJ, et al. Herpes zoster and postherpetic neuralgia: incidence and risk indicators using a general practice research database. Fam Pract 2002;19:471-5.

44. de Melker H, Berbers G, Hahné S, et al. The epidemiology of varicella and herpes zoster in the Netherlands: implications for varicella zoster virus vaccination. Vaccine 2006;24:3946-52.

45. Opstelten W, Van Essen GA, Schellevis F, et al. Gender as an independent risk factor for herpes zoster: a population-based prospective study. Ann Epidemiol 2006;16:692-5.

46. Pierik JG, Gumbs PD, Fortanier SA, et al. Epidemiological characteristics and societal burden of varicella zoster virus in the Netherlands. BMC Infect Dis 2012;12:110.

47. Richard J-L, Zimmermann H. Herpès zoster 1998-2001. Sentinella-Jahresbericht, 2001.

48. Bilcke J, Ogunjimi B, Marais C, et al. The health and economic burden of chickenpox and herpes zoster in Belgium. Epidemiol Infect 2012;140:2096-109.

49. Pérez-Farinós N, Ordobás M, García-Fernández C, et al. Varicella and herpes zoster in Madrid, based on the Sentinel General Practitioner Network: 1997-2004. BMC Infect Dis 2007;7:59.

50. García Cenoz M, Castilla J, Montes Y, et al. [Varicella and herpes zoster incidence prior to the introduction of systematic child vaccination in Navarre, 2005-2006]. An Sist Sanit Navar 2008;31:71-80.

51. Cebrián-Cuenca AM, Díez-Domingo J, Rodríguez MS, et al. Epidemiology of herpes zoster infection among patients treated in primary care centres in the Valencian community (Spain). BMC Fam Pract 2010;11:33.

52. Morant-Talamante N, Diez-Domingo J, Martínez-Úbeda S, et al. Herpes zoster surveillance using electronic databases in the Valencian community (Spain). BMC Infect Dis 2013;13:463.

53. Esteban-Vasallo MD, Gil-Prieto R, Domínguez-Berjón MF, et al. Temporal trends in incidence rates of herpes zoster among patients treated in primary care centers in Madrid (Spain), 2005-2012. $J$ Infect 2014;68:378-86.

54. di Luzio Paparatti U, Arpinelli F, Visonà G. Herpes zoster and its complications in Italy: an observational survey. $J$ Infect 1999;38:116-20.

55. Di Legami V, Gianino MM, Ciofi degli Atti M, et al. Epidemiology and costs of herpes zoster: background data to estimate the impact of vaccination. Vaccine 2007;25:7598-604.

56. Gialloreti LE, Merito M, Pezzotti P, et al. Epidemiology and economic burden of herpes zoster and post-herpetic neuralgia in Italy: a retrospective, population-based study. BMC Infect Dis 2010;10:230

57. Helgason S, Sigurdsson J, Gudmundsson S. The clinical course of herpes zoster: a prospective study in primary care. Eur J Gen Pract 1996;2:12-16

58. Studahl M, Petzold M, Cassel T. Disease burden of herpes zoster in Sweden-predominance in the elderly and in women-a register based study. BMC Infect Dis 2013;13:586.

59. Lionis $\mathrm{CD}$, Vardavas $\mathrm{Cl}$, Symvoulakis EK, et al. Measuring the burden of herpes zoster and post herpetic neuralgia within primary care in rural Crete, Greece. BMC Fam Pract 2011;12:136.

60. Weitzman $\mathrm{D}$, Shavit $\mathrm{O}$, Stein $\mathrm{M}$, et al. A population based study of the epidemiology of Herpes Zoster and its complications. J Infect 2013;67:463-9.
61. Alakloby OM, AlJabre SH, Randhawa MA, et al. Herpes zoster in eastern Saudi Arabia: clinical presentation and management. J Drugs Dermatol 2008;7:457-62.

62. Stein AN, Britt $\mathrm{H}$, Harrison $\mathrm{C}$, et al. Herpes zoster burden of illness and health care resource utilisation in the Australian population aged 50 years and older. Vaccine 2009;27:520-9.

63. Jih JS, Chen YJ, Lin MW, et al. Epidemiological features and costs of herpes zoster in Taiwan: a national study 2000 to 2006. Acta Derm Venereol 2009;89:612-16.

64. Lin YH, Huang LM, Chang IS, et al. Disease burden and epidemiology of herpes zoster in pre-vaccine Taiwan. Vaccine 2010;28:1217-20.

65. Chao DY, Chien YZ, Yeh YP, et al. The incidence of varicella and herpes zoster in Taiwan during a period of increasing varicella vaccine coverage, 2000-2008. Epidemiol Infect 2012;140: $1131-40$

66. Park S, Kim J, Kim C, et al. A clinical study on herpes zoster during the last 10-year-period (1994-2003). Korean J Dermatol 2004;42:1531-5

67. Choi WS, Noh JY, Huh JY, et al. Disease burden of herpes zoster in Korea. J Clin Virol 2010;47:325-9.

68. Toyama N, Shiraki K; Society of the Miyazaki Prefecture Dermatologists. Epidemiology of herpes zoster and its relationship to varicella in Japan: a 10-year survey of 48,388 herpes zoster cases in Miyazaki prefecture. J Med Virol 2009;81:2053-8.

69. Vujacich C, Poggi E, Cecchini D, et al. [Clinical and epidemiological aspects of herpes zoster]. Medicina (B Aires) 2008:68:125-8.

70. Castro L, Chen S. Zoster: mais frequentes entre jovens que entre idosos/zoster: is more frequent among youngers than aged. An Bras Dermatol 1990;65:129-33.

71. Gaitan M. Herpes zoster y cancer: relaciones entre estas dos enfermedades/herpes zoster and cancer: relationship between these 2 diseases. Acta Med Colomb 1981;6:287-93.

72. Patel MS, Gebremariam A, Davis MM. Herpes zoster-related hospitalizations and expenditures before and after introduction of the varicella vaccine in the United States. Infect Control Hosp Epidemiol 2008;29:1157-63.

73. Jackson LA, Reynolds MA, Harpaz R. Hospitalizations to treat herpes zoster in older adults: causes and validated rates. Clin Infect Dis 2008;47:754-9.

74. Civen R, Chaves SS, Jumaan A, et al. The incidence and clinica characteristics of herpes zoster among children and adolescents after implementation of varicella vaccination. Pediatr Infect Dis J 2009;28:954-9.

75. Yawn B, Wollan $\mathrm{P}$, Bialek S, et al. Trends in herpes zoster prevalence in a population based cohort from 1945 to 2008. 48th Annual Meeting of the Infectious Diseases Society of America. 2010

76. Maclntyre CR, Chu CP, Burgess MA. Use of hospitalization and pharmaceutical prescribing data to compare the prevaccination burden of varicella and herpes zoster in Australia. Epidemiol Infect 2003;131:675-82.

77. Carville KS, Riddell MA, Kelly HA. A decline in varicella but an uncertain impact on zoster following varicella vaccination in Victoria, Australia. Vaccine 2010;28:2532-8.

78. Nelson MR, Britt HC, Harrison CM. Evidence of increasing frequency of herpes zoster management in Australian genera practice since the introduction of a varicella vaccine. Med J Aust 2010;193:110-13.

79. Jardine A, Conaty SJ, Vally H. Herpes zoster in Australia: evidence of increase in incidence in adults attributable to varicella immunization? Epidemiol Infect 2011;139:658-65.

80. Wu PY, Wu HD, Chou TC, et al. Varicella vaccination alters the chronological trends of herpes zoster and varicella. PLOS ONE 2013;8:e77709.

81. Galil K, Choo PW, Donahue JG, et al. The sequelae of herpes zoster. Arch Intern Med 1997;157:1209-13.

82. Thyregod HG, Rowbotham MC, Peters M, et al. Natural history of pain following herpes zoster. Pain 2007;128:148-56.

83. Klompas M, Kulldorff M, Vilk Y, et al. Herpes zoster and postherpetic neuralgia surveillance using structured electronic data. Mayo Clin Proc 2011;86:1146-53.

84. Katz J, McDermott MP, Cooper EM, et al. Psychosocial risk factors for postherpetic neuralgia: a prospective study of patients with herpes zoster. J Pain 2005;6:782-90.

85. Drolet M, Brisson M, Schmader K, et al. Predictors of postherpetic neuralgia among patients with herpes zoster: a prospective study J Pain 2010;11:1211-21. 
86. Jung BF, Johnson RW, Griffin DR, et al. Risk factors for postherpetic neuralgia in patients with herpes zoster. Neurology 2004;62:1545-51.

87. Coen PG, Scott F, Leedham-Green M, et al. Predicting and preventing post-herpetic neuralgia: are current risk factors useful in clinical practice? Eur J Pain 2006;10:695-700.

88. Bouhassira D, Chassany $\mathrm{O}$, Gaillat J, et al. Patient perspective on herpes zoster and its complications: an observational prospective study in patients aged over 50 years in general practice. Pain 2012;153:342-9.

89. Meister W, Neiss A, Gross G, et al. A prognostic score for postherpetic neuralgia in ambulatory patients. Infection 1998;26:359-63.

90. Weinke T, Edte A, Schmitt S, et al. Impact of herpes zoster and post-herpetic neuralgia on patients' quality of life: a patient-reported outcomes survey. Z Gesundh Wiss 2010;18:367-74.

91. Opstelten W, Zuithoff NP, van Essen GA, et al. Predicting postherpetic neuralgia in elderly primary care patients with herpes zoster: prospective prognostic study. Pain 2007;132(Suppl 1):S52-9.

92. Sicras-Mainar A, Navarro-Artieda R, Ibáñez-Nolla J, et al. [Incidence, resource use and costs associated with postherpetic neuralgia: a population-based retrospective study]. Rev Neurol 2012;55:449-61.

93. Cebrián-Cuenca AM, Díez-Domingo J, San-Martín-Rodríguez M, et al. Epidemiology and cost of herpes zoster and postherpetic neuralgia among patients treated in primary care centres in the Valencian community of Spain. BMC Infect Dis 2011;11:302.

94. Volpi A, Gatti A, Pica F, et al. Clinical and psychosocial correlates of post-herpetic neuralgia. J Med Virol 2008;80:1646-52.

95. Parruti G, Tontodonati M, Rebuzzi C, et al. Predictors of pain intensity and persistence in a prospective Italian cohort of patients with herpes zoster: relevance of smoking, trauma and antiviral therapy. BMC Med 2010;8:58.

96. Bricout $\mathrm{H}$, Perinetti E, Marchettini $\mathrm{P}$, et al. Predictor factors for the presence of post herpetic neuralgia at 3 months in herpes zoster patients aged 50 and over in Italy: results from a gp-based observational prospective multicenter study. Value Health 2013;16: A343.

97. Helgason S, Petursson G, Gudmundsson S, et al. Prevalence of postherpetic neuralgia after a first episode of herpes zoster: prospective study with long term follow up. BMJ 2000;321:794-6.

98. Lukas K, Edte A, Bertrand I. The impact of herpes zoster and post-herpetic neuralgia on quality of life: patient-reported outcomes in six European countries. J Public Health(Germany) 2012;20:441-51.

99. Tsai TF, Yu HS, Rampakakis E, et al. Assessment of burden of illness due to herpes zoster and predictors of outcomes in Taiwan: a prospective observational study. Int $J$ Infect Dis 2012;16:e115.

100. Kurokawa I, Kumano K, Murakawa K, et al. Clinical correlates of prolonged pain in Japanese patients with acute herpes zoster. $J$ Int Med Res 2002;30:56-65.

101. Kurokawa I, Murakawa K, Kumano K. The change in zoster-associated pain treated with oral valaciclovir in immunocompetent patients with acute herpes zoster. Int J Clin Pract 2007:61:1223-9.

102. Kanbayashi $\mathrm{Y}$, Onishi K, Fukazawa K, et al. Predictive factors for postherpetic neuralgia using ordered logistic regression analysis. Clin J Pain 2012;28:712-14.

103. Ro BI, Go JW, Kim SH, et al. A clinical study on 2096 patients with herpes zoster during the four-year-period (2007-2011). J Dermato 2012;39:10.

104. Song HJ, Choi WS, Lee JD, et al. Measuring herpes zoster and post-herpetic neuralgia associated burden of illness and health care utilization and costs in Korea: a clinical epidemiological study. Int J Infect Dis 2012;16:e111.

105. Cho SI, Lee $\mathrm{CH}$, Park $\mathrm{GH}$, et al. Use of S-LANSS, a tool for screening neuropathic pain, for predicting postherpetic neuralgia in patients after acute herpes zoster events: a single-center, 12-month, prospective cohort study. J Pain 2014;15:149-56.

106. Tunsuriyawong S, Puavilai S. Herpes zoster, clinical course and associated diseases: a 5-year retrospective study at Tamathibodi Hospital. J Med Assoc Thai 2005;88:678-81.

107. Aunhachoke K, Bussaratid V, Chirachanakul P, et al. Measuring herpes zoster, zoster-associated pain, post-herpetic neuralgiaassociated loss of quality of life, and healthcare utilization and costs in Thailand. Int J Dermatol 2011;50:428-35.

108. Goh CL, Khoo L. A retrospective study of the clinical presentation and outcome of herpes zoster in a tertiary dermatology outpatient referral clinic. Int J Dermatol 1997;36:667-72.
109. Chaudhary SD, Dashore A, Pahwa US. A clinico-epidemiologic profile of herpes zoster in North India. Indian J Dermatol Venereol Leprol 1987;53:213-16.

110. Abdul Latheef EN, Pavithran K. Herpes zoster: a clinical study in 205 patients. Indian J Dermatol 2011;56:529-32.

111. Vujacich C, De Wouters L, Margari A, et al. Assessment of burden of illness due to herpes zoster in Argentina: a prospective observational study. Value Health 2013;16:A668.

112. Oster G, Harding G, Dukes E, et al. Pain, medication use, and health-related quality of life in older persons with postherpetic neuralgia: results from a population-based survey. J Pain 2005;6:356-63.

113. Reda H, Greene K, Rice FL, et al. Natural history of herpes zoster: late follow-up of 3.9 years $(n=43)$ and 7.7 years $(n=10)$. Pain 2013;154:2227-33.

114. Watson CP, Oaklander AL. Postherpetic neuralgia. Pain Pract 2002;2:295-307.

115. Hope-Simpson RE. Postherpetic neuralgia. J R Coll Gen Pract 1975;25:571-5.

116. Bowsher D. The lifetime occurrence of herpes zoster and prevalence of post-herpetic neuralgia: a retrospective survey in an elderly population. Eur J Pain 1999;3:335-42.

117. McKendrick MW, Ogan P, Care CC. A 9 year follow up of post herpetic neuralgia and predisposing factors in elderly patients following herpes zoster. J Infect 2009;59:416-20.

118. van Seventer R, Sadosky A, Lucero M, et al. A cross-sectional survey of health state impairment and treatment patterns in patients with postherpetic neuralgia. Age Ageing 2006;35:132-7.

119. Epstein E. Recurrences in herpes zoster. Cutis 1980;26: 378-9.

120. Yawn BP, Wollan PC, Kurland MJ, et al. Herpes zoster recurrences more frequent than previously reported. Mayo Clin Proc 2011;86:88-93.

121. Jeong S, Kim I. Recurrence rate of herpes zoster during the previous decade. Korean J Dermatol 2012;50:287-9.

122. Tseng HF, Chi M, Smith $\mathrm{N}$, et al. Herpes zoster vaccine and the incidence of recurrent herpes zoster in an immunocompetent elderly population. J Infect Dis 2012;206:190-6.

123. Ghaznawi N, Virdi A, Dayan A, et al. Herpes zoster ophthalmicus: comparison of disease in patients 60 years and older versus younger than 60 years. Ophthalmology 2011;118:2242-50.

124. Borkar DS, Tham VM, Esterberg E, et al. Incidence of herpes zoster ophthalmicus: results from the pacific ocular inflammation study. Ophthalmology 2013;120:451-6.

125. Bayu S, Alemayehu W. Clinical profile of herpes zoste ophthalmicus in Ethiopians. Clin Infect Dis 1997;24:1256-60.

126. Liesegang TJ. Herpes zoster ophthalmicus natural history, risk factors, clinical presentation, and morbidity. Ophthalmology 2008;115(Suppl 2):S3-12.

127. Zaal MJ, Völker-Dieben HJ, D'Amaro J. Visual prognosis in immunocompetent patients with herpes zoster ophthalmicus. Acta Ophthalmol Scand 2003;81:216-20.

128. Womack LW, Liesegang TJ. Complications of herpes zoster ophthalmicus. Arch Ophthalmol 1983;101:42-5.

129. Harding SP, Lipton JR, Wells JC. Natural history of herpes zoster ophthalmicus: predictors of postherpetic neuralgia and ocular involvement. Br J Ophthalmol 1987;71:353-8.

130. Yawn BP, Wollan PC, St Sauver JL, et al. Herpes zoster eye complications: rates and trends. Mayo Clin Proc 2013;88: 562-70.

131. Lin F, Hadler JL. Epidemiology of primary varicella and herpes zoster hospitalizations: the pre-varicella vaccine era. J Infect Dis 2000;181:1897-905

132. Coplan P, Black S, Rojas C, et al. Incidence and hospitalization rates of varicella and herpes zoster before varicella vaccine introduction: a baseline assessment of the shifting epidemiology of varicella disease. Pediatr Infect Dis J 2001;20:641-5.

133. Gil A, San-Martín M, Carrasco P, et al. Epidemiology of severe varicella-zoster virus infection in Spain. Vaccine 2004;22: 3947-51

134. Gil A, Gil R, Alvaro A, et al. Burden of herpes zoster requiring hospitalization in Spain during a seven-year period (1998-2004). BMC Infect Dis 2009;9:55.

135. Bayas JM, Gil R, Llupia A, et al. Hospitalizations due to herpes zoster and postherpetic neuralgia in Catalonia, 1998-2003. Vacunas 2011;12:122-8.

136. Gil-Prieto R, Walter S, Gonzalez-Escalada A, et al. Different vaccination strategies in Spain and its impact on severe varicella and zoster. Vaccine 2014;32:277-83. 
137. Mesquita M, Froes F. Hospital admissions for herpes zoster in Portugal between 2000 and 2010. Acta Med Port 2013;26:531-6.

138. Mahamud A, Marin M, Nickell SP, et al. Herpes zoster-related deaths in the United States: validity of death certificates and mortality rates, 1979-2007. Clin Infect Dis 2012;55:960-6.

139. Yawn BP, Wollan P, St Sauver J. Comparing shingles incidence and complication rates from medical record review and administrative database estimates: how close are they? Am J Epidemiol 2011;174:1054-61.

140. Lee BW. Review of varicella zoster seroepidemiology in India and Southeast Asia. Trop Med Int Health 1998;3:886-90.

141. Vergara-Castañeda A, Escobar-Gutiérrez A, Ruiz-Tovar K, et al. Epidemiology of varicella in Mexico. J Clin Virol 2012;55:51-7.

142. Nagasako EM, Johnson RW, Griffin DR, et al. Geographic and racial aspects of herpes zoster. J Med Virol 2003;70(Suppl 1): S20-3.

143. Schmidt-Chanasit J, Sauerbrei A. Evolution and world-wide distribution of varicella-zoster virus clades. Infect Genet Evol 2011;11:1-10.

144. Loparev VN, Gonzalez A, Deleon-Carnes M, et al. Global identification of three major genotypes of varicella-zoster virus: longitudinal clustering and strategies for genotyping. $J$ Virol 2004;78:8349-58.
145. Morse SS. Factors in the emergence of infectious diseases. Emerg Infect Dis 1995;1:7-15.

146. Sengupta N, Taha Y, Scott FT, et al. Varicella-zoster-virus genotypes in East London: a prospective study in patients with herpes zoster. J Infect Dis 2007;196:1014-20.

147. Sauerbrei A, Wutzler P. Different genotype pattern of varicella-zoster virus obtained from patients with varicella and zoster in Germany. J Med Virol 2007;79:1025-31.

148. Wahrendorf M, Reinhardt JD, Siegrist J. Relationships of disability with age among adults aged 50 to 85: evidence from the United States, England and continental Europe. PLOS ONE 2013;8: e71893.

149. Johnson RW, Wasner G, Saddier P, et al. Postherpetic neuralgia: epidemiology, pathophysiology and management. Expert Rev Neurother 2007;7:1581-95.

150. Dworkin RH, Carrington D, Cunningham A, et al. Assessment of pain in herpes zoster: lessons learned from antiviral trials. Antiviral Res 1997;33:73-85.

151. Coplan PM, Schmader K, Nikas A, et al. Development of a measure of the burden of pain due to herpes zoster and postherpetic neuralgia for prevention trials: adaptation of the brief pain inventory. J Pain 2004;5:344-56. 